\title{
WAR AND FOREIGN DEBT SETTLEMENT IN EARLY REPUBLICAN SPANISH AMERICA *
}

\author{
RICHARD SICOTTE \\ University of Vermont ${ }^{\mathrm{a}}$ \\ CATALINA VIZCARRA \\ University of Vermont
}

\begin{abstract}
Upon gaining independence, most Spanish American countries had accumulated a substantial external debt, and by 1829 each defaulted. It took decades for these countries to settle their debts and even longer for them to access new loans. We argue that a major factor influencing the pattern of debt service was the incidence of war. War created incentives for governments to channel scarce resources to «emergency» spending and domestic debt service, rather than to the repayment of the foreign debt. Interestingly, we detect an asymmetry between countries long in good standing with creditors and those that had only recently settled. Countries that had established a longer record of continuous debt service were far less likely to default in times of war. We also find that international wars were responsible for the largest effects.
\end{abstract}

Keywords: Spanish America, sovereign debt, default, war JEL Classification: F34, N26, N46

* Received 01/05/2009. Accepted 04/23/2009. We thank participants at the 2007 International Society for the New Institutional Economics conference, and at the 2008 New Frontiers in Latin American History conference for valuable comments. The usual disclaimers apply.

a Department of Economics. 239 Old Mill, 94 University Place, Burlington VT 05405. E-mail addresses: Richard.Sicotte@uvm.edu, Catalina.Vizcarra@uvm.edu. 


\section{RESUMEN}

En este artículo sugerimos que un factor que determinó en buena medida la trayectoria del pago de la deuda externa de los países hispanoamericanos en las primeras décadas de su vida independiente, fue la enorme incidencia de conflictos armados en la región. Las frecuentes guerras crearon incentivos para que éstos dirigieran sus escasos recursos a gastos militares y al servicio de la deuda interna en vez de a la deuda exterior. Un resultado interesante es la asimetría que se registra entre los países que llegaron a renegociar su deuda exitosamente y mantuvieron su servicio por largos períodos de tiempo, y la de aquellos que no tuvieron mayor éxito en sus renegociaciones. En el caso de estos últimos, las guerras registraron efectos negativos mayores. También demostramos que las guerras internacionales tuvieron los efectos más dramáticos.

Palabras clave: hispanoamérica, deuda externa, deuda impagada, guerra

\section{INTRODUCTION}

Upon gaining independence, most Spanish American countries had accumulated a large external debt in the form of sovereign bonds floated in London. By 1829, each had defaulted. It took years, even decades, for these countries to re-schedule these debts and even longer for them to access new loans. Carlos Marichal (1989), in his masterful study of Latin America's debt crises, argues that the region passed through several "loan cycles» between 1820 and 1930, each of which witnessed a period of massive capital inflows followed by a string of defaults connected to the upswings and downswings of business cycles in creditor nations.

This paper complements Marichal's important contribution with an exploration of the role that political upheavals and wars might have played in molding the observed patterns of settlement and default. Political historians, in considering the early independence period, unfailingly note the prevalence of uprisings and civil wars ${ }^{1}$. More recently, economic historians such as North, Summerhill and Weingast (2000), Bates, Coatsworth and Williamson (2007), and Coatsworth (2008), have argued that the extreme violence and instability had institutional roots, and that the wars themselves were destructive economically and were a proximate cause of rates of economic growth that were much slower than in the United States and several Western European countries. The parallels between the «lost decades» of

1 See Safford (1992). 
political disorder and economic decline and the lengthy period of default are tantalizing.

This paper offers a comparative study of the relationship between war and external debt in Spanish America in the fifty years after independence. The key questions are whether war contributed to default, and as a corollary, whether war impeded the successful settlement of external debts that were in default. To some it may seem obvious that the financial stresses of war might increase the probability of default on the external debt. However, the relationship between war and debt is more complex than it appears at first sight. Governments may find it extremely important to maintain (or establish) external debt service, even in times of war, for two reasons. First, foreign capital has the potential to provide enormous resources to the state, thus facilitating its ability to successfully carry out military operations. Second, some of the wars fought by Spanish American countries - most poignantly in the case of Mexico- were fought with European countries that justified their initiation of the conflict precisely because of the lack of payment of foreign creditors. Thus, in some cases war might provide incentives for debt settlement, rather than impair it.

The literature on sovereign debt demonstrates that the motivations for debt service are complex enough even in the absence of war $^{2}$. The decision to default (or to settle) is a political one that depends upon the incentive structure and beliefs of the relevant political actors. Further, these incentives and beliefs, as well as the macroeconomic fluctuations that affect the ability of a government to service its debt, may or may not be correlated with the incidence of conflict. We would have liked to present a formal direct statistical test of the relative importance of war on default, but the paucity of basic economic data on these countries during this time period precludes the construction of an econometric model that is both properly specified and has sufficient degrees of freedom. Alternatively, our approach is three-pronged: First, we examine the descriptive statistics and correlations between wars, defaults and settlements. To accomplish this, we construct a new and improved database on the external debt service histories of Spanish American countries from 1830 to 1870. We compare these series with our own database of wars, which augments the Gleditsch (2004) revision of the Correlates of War project (Singer and Small, 1994). The data show that wars are associated with most of the defaults during the period of our study. We also find that debt settlements occurred mostly during peaceful interludes. In addition, we detect an asymmetry between countries long in good standing with creditors and those that had only recently settled.

2 There is an extensive literature on the economics of sovereign debt which has been successful in identifying a number of potential rationales for servicing foreign debt obligations. These include reputation so as to ensure access to future credit (see for example Eaton and Gersovitz, 1981, and Tomz, 2007) and fear of military and or economic sanctions (see Bulow and Rogoff, 1989 and Mitchener and Weidenmier, 2005). 
Countries that had established a longer record of continuous debt service were far less likely to default in times of war than those that had only recently settled their debt. Furthermore, many of the former countries did indeed access international capital markets to finance wars - namely, Argentina, Chile and Peru. Only Venezuela was able to float a new loan during civil war despite having a checkered credit history.

In order to obtain direct evidence on how wars affected government finances and budgetary choices we examine detailed data from the countries' respective Ministerios de Hacienda (Treasuries). The dramatic fiscal impacts of certain wars are clearly observable in the data, and we document how some of these wars affected default and re-scheduling decisions. We also conduct econometric tests for structural breaks in the time series of sovereign debt yield spreads versus the British consol. The bond price data from which the spreads are calculated are monthly series over the years 1830 to 1869 on the London Stock Exchange. We find that the breaks causing significant deterioration in the yield spread (indicating a reduced probability of settlement or an increased probability of default) are frequently associated with wars, and often the same wars whose importance was suggested by the Treasury data. Moreover, the data suggests that international wars - not civil wars - had the most significant effects. At least for some countries, a greater threat to fiscal solvency seems to have been posed by foreign intervention.

\section{LOANS, DEFAULTS AND SETTLEMENTS}

Beginning in 1822, the new countries of Spanish America contracted loans with major financial firms in London to achieve and consolidate their independence and to finance the new states and militaries ${ }^{3}$. Table 1 gives the basic details of these loans. The amounts varied from one million pounds each to Buenos Aires and Chile, to 6.4 million and 6.75 million pounds to Mexico and Gran Colombia, respectively ${ }^{4}$.

Default came quickly, with Peru the first to miss payment in April 1826 and Buenos Aires the last to join the ranks in January 1828. The literature attributes the defaults to several factors, including continuing war, and a severe

3 The debt of the Central American Federation is omitted from this study, because the data are much more sparse. In the 1830s the responsibility for the Central American loan was split among the former members of the federation. Brazil and Haiti are omitted from our study as they differ from Spanish American countries in many critical ways, particularly insofar as their political history and institutions.

4 An analysis of the degree to which the new countries were «fleeced» by savvy London bankers is beyond the scope of this paper. See Marichal (1989) Dawson (1990) and Flandreau and Flores (2007) for a discussion. For our purpose it is sufficient to note that the countries began nationhood encumbered with foreign debt. 
TABLE 1

SPANISH-AMERICAN SOVEREIGN LOANS

\begin{tabular}{|c|c|c|c|c|c|c|c|}
\hline Country * & $\begin{array}{c}\text { (1) } \\
\text { Date } \\
\text { of } \\
\text { Loan }\end{array}$ & $\begin{array}{c}\text { (2) } \\
\text { Amount } \\
\text { (pounds } \\
\text { sterling) }\end{array}$ & $\begin{array}{c}(3) \\
\text { Interest } \\
\text { Rate }\end{array}$ & $\begin{array}{l}(4) \\
\text { Issue } \\
\text { Price }\end{array}$ & $\begin{array}{c}(5) \\
\text { Date } \\
\text { of } \\
\text { Default }\end{array}$ & $\begin{array}{c}(6) \\
\text { Dates of } \\
\text { Re-scheduling } \\
\text { Agreements }\end{array}$ & $\begin{array}{c}(7) \\
\text { Debt } \\
\text { Service ** }\end{array}$ \\
\hline $\begin{array}{c}\text { Buenos } \\
\text { Aires }\end{array}$ & 1824 & $1,000,000$ & 6 & 85 & 1828 & 1857 & 60,000 \\
\hline Chile & 1822 & $1,000,000$ & 6 & 70 & 1826 & 1842 & 60,000 \\
\hline $\begin{array}{l}\text { Gran } \\
\text { Colombia } * * *\end{array}$ & $\begin{array}{l}1822 \\
1824\end{array}$ & $\begin{array}{l}2,000,000 \\
4,750,000\end{array}$ & $\begin{array}{l}6 \\
6\end{array}$ & $\begin{array}{l}84 \\
88\end{array}$ & $\begin{array}{l}1826 \\
1826\end{array}$ & - & 405,000 \\
\hline Ecuador & & & & & & 1855 & \\
\hline New Granada & & & & & & 1845,1861 & \\
\hline Venezuela & & & & & & 1840,1859 & \\
\hline Mexico & $\begin{array}{l}1824 \\
1825\end{array}$ & $\begin{array}{l}3,200,000 \\
3,200,000\end{array}$ & $\begin{array}{l}5 \\
6\end{array}$ & $\begin{array}{l}58 \\
89\end{array}$ & $\begin{array}{l}1827 \\
1827\end{array}$ & $\begin{array}{c}1831,1837,1846 \\
1851\end{array}$ & 352,000 \\
\hline Peru & $\begin{array}{l}1822 \\
1824 \\
1825\end{array}$ & $\begin{array}{l}450,000 \\
750,000 \\
616,000\end{array}$ & $\begin{array}{l}6 \\
6 \\
6\end{array}$ & $\begin{array}{l}88 \\
82 \\
78\end{array}$ & $\begin{array}{l}1826 \\
1826 \\
1826\end{array}$ & 1849 & 108,960 \\
\hline
\end{tabular}

Sources: Columns 1-4: Marichal (1989), p. 28. Column 5: Dawson, chapters 6-8. Column 6: Fenn's Compendium, various years, Costeloe, Times of London. Column 7: Authors' calculations based on Amaral (1995), Resumen de la Hacienda de Chile, Memoria de Hacienda de Colombia (1826), Rodríguez (1985), Memoria de Hacienda de Nueva Granada, Memoria de Hacienda de Venezuela, Tantalean Arbulú (1983), Tenenbaum (1986).

Notes:

* The Central American Confederation, which contracted a loan for 163,300 pounds, is not included.

** Debt service is approximated by taking the annual interest charges on the full principal. The amortization charges are only known for some of the cases, and were typically $1 / 2$ per cent or 1 per cent per year. Thus, the debt service estimates here underestimate total debt service by a small amount.

*** Gran Colombia split into Ecuador, New Granada and Venezuela subsequent to contracting the loan.

commercial crisis with intercontinental dimensions (Marichal, 1989; Dawson, 1990; Neal, 1998). In many cases, default was averted temporarily because a portion of the loan proceeds had been held back in London to cover the first few dividend payments. Just prior to, and in the period immediately following the initial default, several of the countries directed their diplomats in London and Paris to try to contract new foreign loans to cover dividend payments on the original loans. In at least one case, potential creditors offered terms that were refused ${ }^{5}$.

The re-scheduling history of these countries is assembled in Table 2. The table shows the defaulted principal and interest at the time of re-scheduling. A major problem resulting from default was the accumulation of interest arrears. This became a major issue for the Spanish American countries be-

\footnotetext{
5 Dawson (1990) refers to an offer in Paris to loan to Peru at a 40 per cent discount.
} 
cause of the length of time that they were in default. Re-scheduling packages often included retiring old bonds, and issuing two classes of new bonds - one for the defaulted principal and one for the interest arrears-. Often there was a (sometimes temporary) reduction in the interest rate on the original principal, and deferred scheduling of payment on the interest arrears (e.g., Mexico, Peru, Venezuela, New Granada). Generally, interest rates were increased incrementally, presumably reflecting a belief in a gradual improvement in government finances over time. When old bonds were not retired, as in Buenos Aires and Chile, new bonds were also issued for the interest arrears. By the time of re-scheduling, it was not uncommon for the foreign debt to have increased dramatically in size because of the capitalization of interest arrears. The agreements typically stipulated that a portion of customs revenues was earmarked for debt service.

Special mention must be made of the case of Gran Colombia. The country ceased to exist around 1830, and its debt was partitioned between Ecuador, New Granada and Venezuela after these countries were created. However, it was only in 1834 that the formula for the partition of the debt was negotiated by New Granada and Venezuela, representatives of Ecuador not being in attendance. In 1838 the governments of all three countries formally recognized the debt according to this agreement. New Granada, present-day Colombia, assumed 50 per cent of the debt and arrears, Venezuela 28.5 per cent, and Ecuador 21.5 per cent. Venezuela was the first of the three to reschedule its debt in 1840, New Granada followed in 1845 and Ecuador in 1855. None kept their original re-scheduling arrangement all the way to $1870^{6}$. Clearly, one of the reasons for the delay in re-scheduling was the dissolution of Gran Colombia and the necessity of negotiating an agreement for dividing its debts among successor states.

The default dates listed on Table 2 are based on a strict definition - the first missed coupon payment-. Sometimes, however, countries were late and continued to make payments, although in arrears. Ecuador missed coupon payments in 1859 and 1860, but it resumed service on its debt until 1869 . During the period 1860-1869 it was always two or more coupon payments behind. Other countries that missed payments paid bondholders in kind through the issue of customs certificates or additional bonds capitalizing the interest arrears. For this reason, in some cases we include a second date in italics that represents the definitive date at which such payments stopped. Several countries had multiple re-schedulings and defaults (Mexico, New Granada and Venezuela). Mexico stands out with four re-scheduling attempts in the period (all which were very short-lived). In contrast, Argentina, Chile and Peru had durable settlements. Chile settled in 1842 and maintained an

${ }^{6}$ See Liehr (1989) for a study of the Gran Colombian debt, with an emphasis on the 1820 s. See also Memoria de la Hacienda de Venezuela (1838-1840), Memoria de la Hacienda de Nueva Granada (1838-1840), and Terán (1896). 


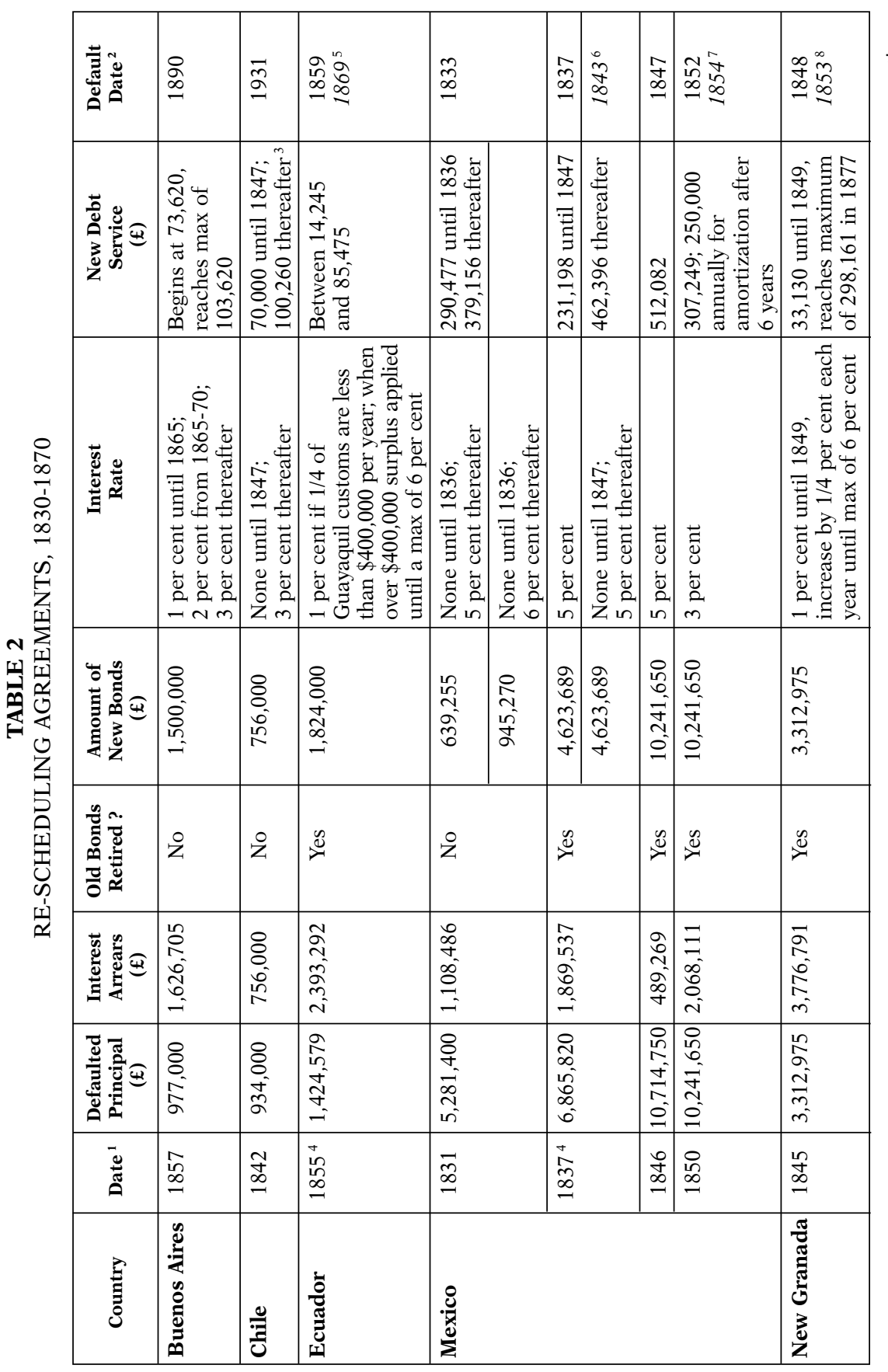




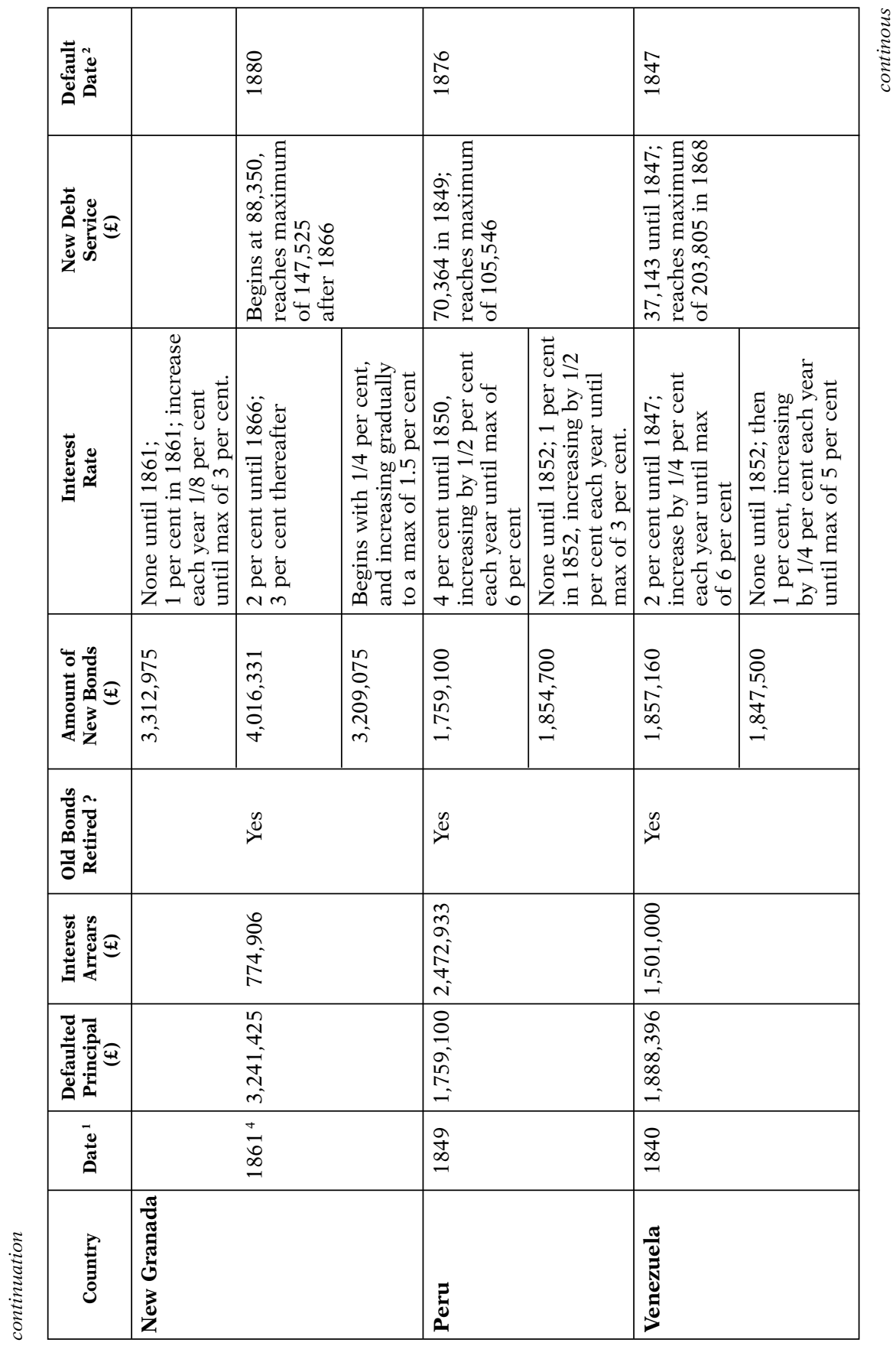



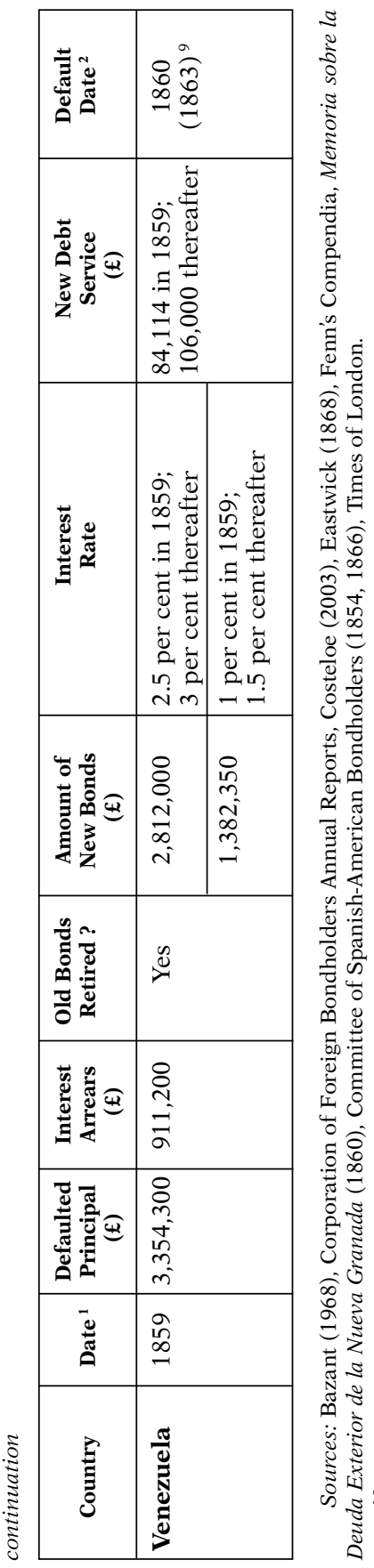

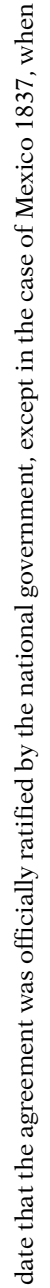
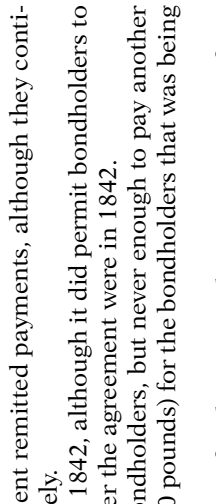

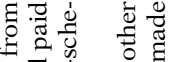

藏

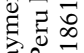

ำ

बन

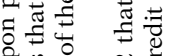

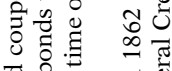

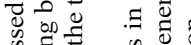

至至

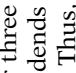

点 0

常焉

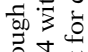

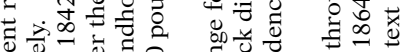

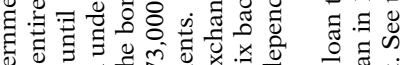

む)

:

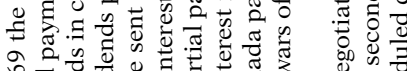

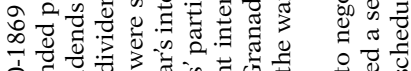

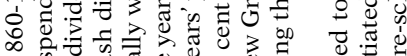

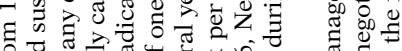

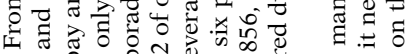

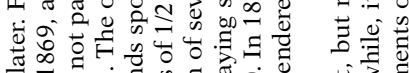

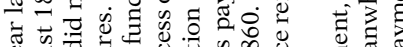

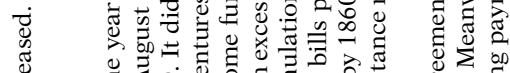

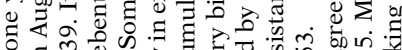

$\exists . \Xi \infty$ 守

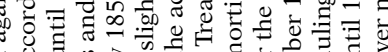

गुं

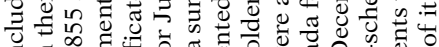

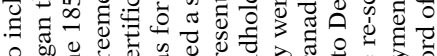

की

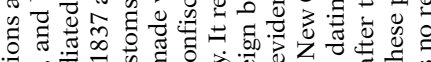

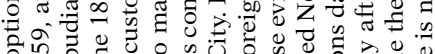

о

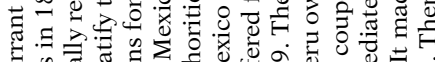

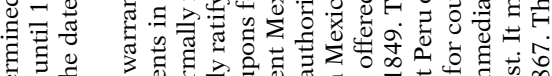
ए ช

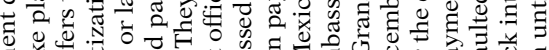

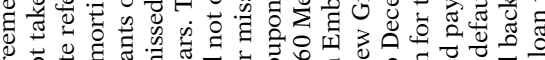

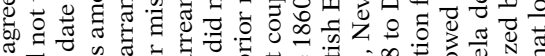

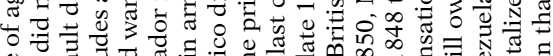

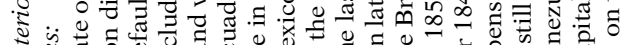

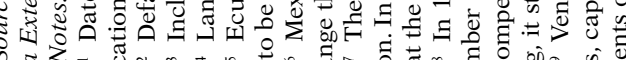

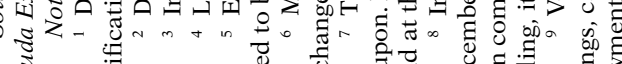
จ

¿

胥总 
excellent reputation as a good debtor for most of the rest of the century. Peru followed in 1849 and serviced its foreign debt faithfully until $1876^{7}$. Buenos Aires settled its debt in 1857 and became part of Argentina, one of the biggest borrowers of the late $19^{\text {th }}$ century until the Baring Crisis.

Table 3 lists the new loans by Spanish American countries up to 1870. The table shows that Argentina, Chile and Peru accounted for the vast majority of the new debt, most of which was earmarked for war expenses, infrastructure investment, and debt conversion. The only country that issued new debt while simultaneously in default on an old debt was Venezuela. However, this loan was floated with the express purpose of trying to regain

TABLE 3

NEW LENDING TO 1870

\begin{tabular}{|c|c|c|c|c|c|}
\hline Country & $\begin{array}{c}\text { (1) } \\
\text { Date } \\
\text { of Loan }\end{array}$ & $\begin{array}{l}\text { (2) Amount } \\
\text { (pounds } \\
\text { sterling) }\end{array}$ & $\begin{array}{c}\text { (3) } \\
\text { Interest } \\
\text { Rate }\end{array}$ & $\begin{array}{l}\text { (4) } \\
\text { Issue } \\
\text { Price }\end{array}$ & $\begin{array}{c}\text { (5) } \\
\text { Reason for Loan }\end{array}$ \\
\hline Argentina & 1866 & 500,000 & 6 & & War expenses \\
\hline $\begin{array}{l}\text { Argentina } \\
\text { Buenos Aires }\end{array}$ & $\begin{array}{l}1868 \\
1870\end{array}$ & $\begin{array}{l}1,950,000 \\
1,034,700\end{array}$ & $\begin{array}{l}6 \\
6 \\
\end{array}$ & $\begin{array}{c}72,5 \\
88\end{array}$ & $\begin{array}{l}\text { War expenses } \\
\text { Railroads, port }\end{array}$ \\
\hline Chile & $\begin{array}{l}1858 \\
1866 \\
1867 \\
1867 \\
1870 \\
\end{array}$ & $\begin{array}{c}1,554,800 \\
450,000 \\
2,000,000 \\
626,700 \\
1,012,700 \\
\end{array}$ & $\begin{array}{l}4.5 \\
6 \\
6 \\
7 \\
5 \\
\end{array}$ & $\begin{array}{c}92 \\
92.5 \\
84 \\
92 \\
83 \\
\end{array}$ & $\begin{array}{l}\text { Railroads, general } \\
\text { expenses } \\
\text { War } \\
\text { Conversion, war } \\
\text { War }\end{array}$ \\
\hline Colombia & 1863 & 200,000 & 6 & & Railroad \\
\hline Peru & $\begin{array}{l}1853 \\
1853 \\
1853 \\
1853 \\
1862 \\
1865 \\
1869 \\
1870 \\
\end{array}$ & \begin{tabular}{|c|}
$2,600,000$ \\
$1,800,000$ \\
800,000 \\
400,000 \\
$5,500,000$ \\
$10,000,000$ \\
290,000 \\
$11,920,000$ \\
\end{tabular} & $\begin{array}{l}4.5 \\
4.5 \\
4.5 \\
4.5 \\
5 \\
5 \\
6 \\
\end{array}$ & $\begin{array}{c}93 \\
83,5 \\
70 \\
82,5 \\
\end{array}$ & $\begin{array}{l}\text { Renegotiation of external debt } \\
\text { Conversion of domestic debt } \\
\text { Conversion of domestic debt } \\
\text { Railroad } \\
\text { Conversion } \\
\text { Conversion, war expenses } \\
\text { Railroad } \\
\text { Railroads }\end{array}$ \\
\hline Venezuela & 1862 & $\begin{array}{l}1,000,000 \\
1,500,000\end{array}$ & 6 & 63 & $\begin{array}{l}\text { War expenses, old claims, } \\
\text { interest in arrears on old } \\
\text { debt, creation of Bank of } \\
\text { Venezuela } \\
\text { Old claims, back pay to } \\
\text { army, roads }\end{array}$ \\
\hline
\end{tabular}

Sources: Fenn's. Compendia, Marichal (1989), Platt (1968), Rippy (1959).

Note: Venezuela issued an additional 210,000 pounds of 6 per cent bonds in 1862 capitalizing the arrears on the interest accumulated to that date from the unsuccessful re-scheduling agreement of 1859 .

${ }^{7}$ For a discussion of the Peruvian case see Vizcarra (2009). 
solvency, the discount was enormous and most of the proceeds simply went to pay off old war debt ${ }^{8}$.

\section{WARS, SETTLEMENTS AND DEFAULTS}

After gaining independence through successful revolutions, most of Spain's former colonies suffered decades of frequent warfare. In some cases, the record of conflict is almost incessant. We discuss two alternative definitions to evaluate the incidence of war in the region. The first is the Gleditsch (2004) revision of Singer and Small's Correlates of War (1992) database. This database is commonly employed in the political science literature. It employs the criterion that counts wars only if more than 1,000 people died per year ${ }^{9}$. A problem with the casualty threshold is that it introduces a bias against recording wars in small countries. For example, Ecuador, a small country, fought a war known as the Guerra de los Chihuahuas in 1833-34 that does not appear in the popular political science database, but was by all accounts a major event in $19^{\text {th }}$ century Ecuadorian history. So we construct a second list by combining those wars examined in Scheina (2002) and Bethell (1987). This list takes a broader definition of wars, so as to include even some shortlived rebellions. In both cases wars are coded as indicator variables: «1» for war; «0» for peace. Clearly, this is an extremely coarse way to measure conflict. The wars themselves were quite heterogeneous in intensity, breadth and origins. However, we are utilizing these data to make a preliminary assessment of the coincidence of debt settlement and repayment with conflict of any sort. We include international wars in our database, because it will be instructive to see the relative importance of international and internal conflict financially and for debt service. Figures 1 and 2 display the patterns that emerge ${ }^{10}$.

In both databases, Buenos Aires and Mexico lead in conflict, with conflict being almost unceasing in Mexico. There are significant differences between the two databases for some countries. Ecuador is particularly under-represented by the Gleditsch measure because of the death threshold, but other countries are also greatly affected. Much early conflict in the 1820s is not detected, and a number of rebellions in the 1830s and 1840s (Ecuador, Mexico, Peru and Venezuela) do not register in the Gleditsch case. Still, even using our alternative criteria, certain interludes of relative peace appear for some countries: Buenos Aires from 1853 to 1858, Chile in the 1840s, New Granada for 1843-1850, Ecuador from 1835-1845, Peru in the late 1840s and

\footnotetext{
${ }^{8}$ The Venezuelan loan was roundly ridiculed in the financial press. See Eastwick (1868), and Committee of Spanish American Bondholders (1866).

9 See Gleditsch (2004, p. 234), for a description of the nuances of the criterion when applied to different types of conflicts.

${ }^{10}$ The underlying list of wars is presented in the Appendix.
} 
FIGURE 1

WAR IN SPANISH AMERICA, 1825-1870

GLEDITSCH - CORRELATES OF WAR CRITERIA

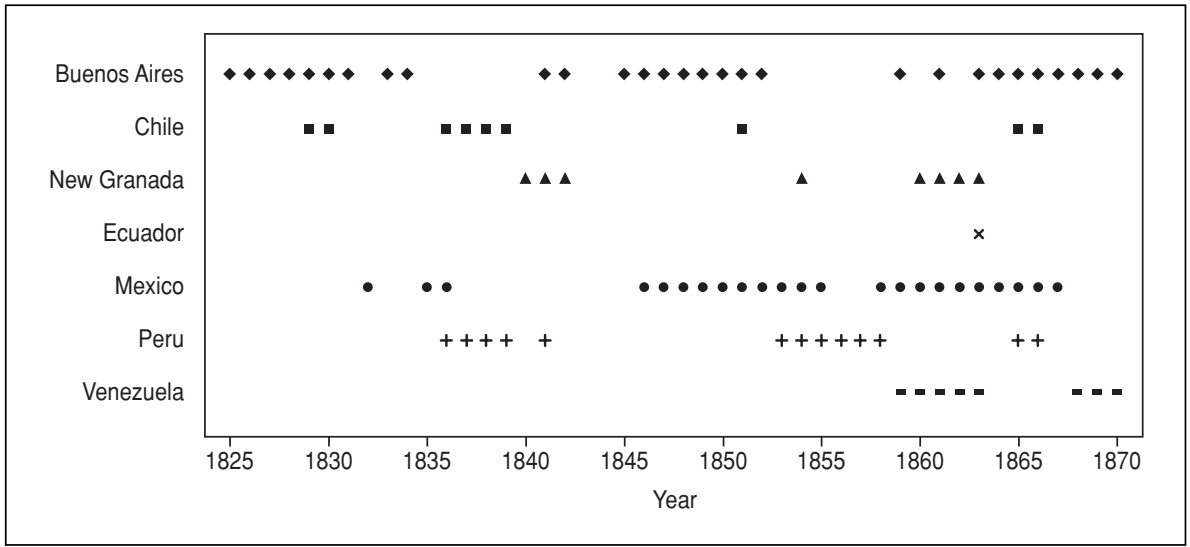

FIGURE 2

WAR IN SPANISH AMERICA, 1825-1870

ALTERNATIVE CRITERIA

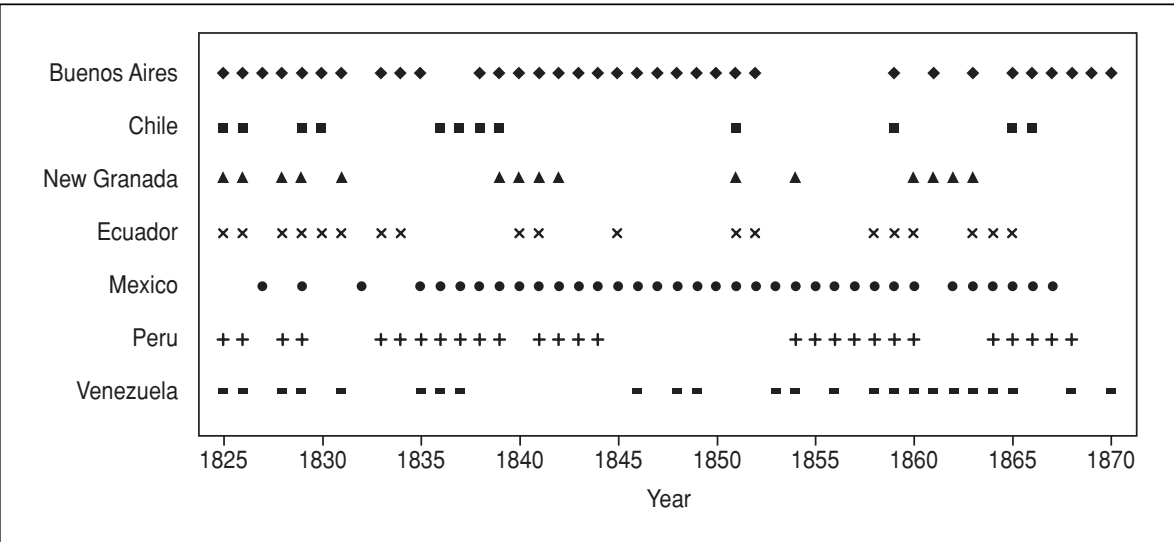

Venezuela from 1838 until 1845. Mexico is the only country that did not have more than a three-year period of relative calm.

In a pooled dataset of indebted Spanish American countries between 1825 and 1870, the correlation coefficient between debt service and war is -0.02 when the Gleditsch definition of war is used, and -0.13 when our alternative is used. Neither correlation is large, suggesting a weak negative relationship between war and debt service (we also calculated these correlation 
coefficients for debt service and lagged war with similar results) ${ }^{11}$. Notwithstanding, simple correlations between war and debt service over the entire period are too broad a measure to provide insightful evidence about the relationship between war and debt service.

As an alternative, in Table 4 we discuss the timing of settlements and default and whether they coincided with military conflict. The table shows that of the twelve debt settlements that were reached during this period, four or five of them occurred during a war (the exact number depending upon whether the Gleditsch or alternative measure of war is used). However, in two of the cases (Mexico 1846 and Venezuela 1859), the settlements came in the months before hostilities had broken out and were followed by an immediate default. Thus, few re-schedulings occurred during military conflict. In contrast, eleven of the fourteen defaults occurred during a time of war, when the broader definition of war is used; five when the Gleditsch criterion is used $^{12}$. Overall, the data on the timing of war, settlement and default is consistent with the view that war may be a cause of default and inhibit successful debt settlement. In the next section we develop an analytical framework that discusses the mechanisms through which war might have affected foreign debt settlement in the region.

TABLE 4

WAR, SETTLEMENTS AND DEFAULTS

\begin{tabular}{|l|c|c|c|}
\hline & Re-schedulings & Defaults (all) & Defaults (serial) \\
\hline War (Gleditsch) & $4 / 12$ & $5 / 14$ & $4 / 9$ \\
\hline War (Alternative) & $5 / 12$ & $11 / 14$ & $6 / 9$ \\
\hline War Lagged (Gleditsch) & & $7 / 14$ & $6 / 9$ \\
\hline War Lagged (Alternative) & & $12 / 14$ & $8 / 9$ \\
\hline
\end{tabular}

\section{WAR AND GOVERNMENT CHOICES}

As discussed above, sovereigns determine whether or not to honor their foreign debt obligations based on cost-benefit calculations that are political in nature. In what follows, we argue that for Spanish American countries in default (all of the region after the revolutionary wars) chronic warfare built in an incentive structure that militated against external debt settlement and

11 The correlations between service and the lagged war are -0.01 (Gleditsch definition) and -0.18 (alternative definition).

12 The proportions are $7 / 14$ and $12 / 14$ when lagged war, rather than coincident war, is employed. The relationships are also strong when serial defaults are isolated (6/9 and $8 / 9$ for the different definitions of war). 
service. In particular, warfare increases the opportunity cost of the funds committed to honor external obligations as the return from military and other emergency domestic spending rise. Countries in default could not float government bonds in foreign financial markets, so they were severely constrained by domestic revenues (ordinary revenues plus domestic credit) ${ }^{13}$. Thus, the new republics had to choose whether to spend scarce funds on external debt service or other items, such as military spending, domestic debt service, and patronage. Each had a different political payoff, which contributed to what one might call the government's utility.

We illustrate the government's decision-making process in an indifference curve-budget line diagram (Figure 3 ). The vertical axis measures the spending on external debt service, and the horizontal axis measures spending on all other items. In this case the budget line reflects the government's total revenue, and has a slope of -1 because one peso spent on external debt signifies one peso less spent elsewhere. The indifference curves have a peculiar shape, each consisting of two vertical segments. The reason for this is that the marginal utility of external debt service is zero up to the amount required to fully service the debt, and it is also zero beyond that amount ${ }^{14}$. The horizontal distance between the two segments of each indifference curve has important political-economic significance. It indicates the amount of additional government spending on other goods and services that would bring the same additional political utility as fully servicing the external debt. The gap will be larger between the two segments as the marginal utility of external

\section{FIGURE 3}

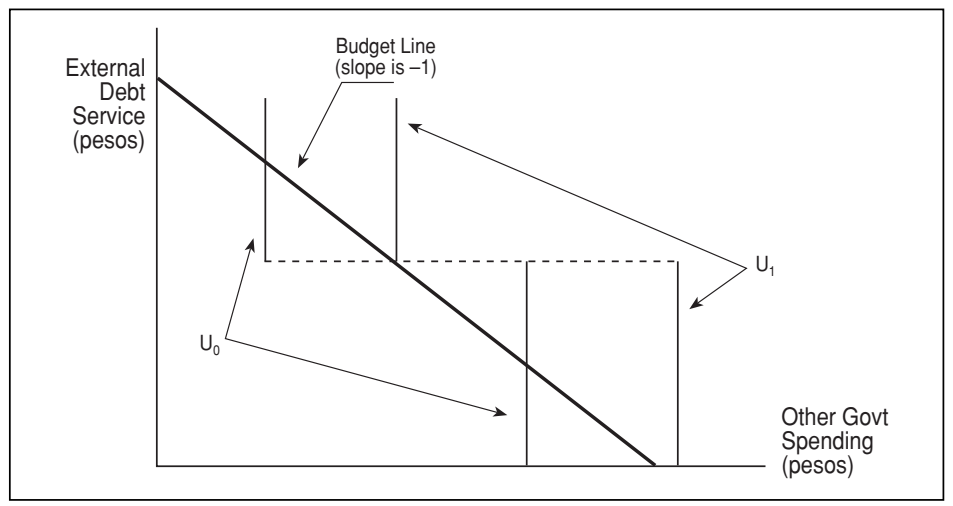

13 On financial markets restrictions to float debt see Borchard (1951, p. xxix). Governments could also print money. The one country in our study that made extensive use of this option was Buenos Aires, see Irigoin (2000).

14 This is a simplifying assumption. A government may gain some utility from partial debt service, and may also gain utility from service over and above the contracted requirement. 
debt service rises relative to the marginal utility of government spending on other goods and services. Because of diminishing returns to domestic spending, the «higher» the indifference curve, the larger the gap between its segments. The equilibrium shown in Figure 3 depicts a government choosing to service its external debt.

We argue that war affected the government choices in two fundamental ways. First, as mentioned above, war is associated with greater returns on military spending and other domestic «emergency» spending relative to foreign debt service. We show below that for most of these countries, domestic borrowing was a vital source of emergency revenue during war, and that governments put great emphasis on maintaining this lifeline of credit. Political instability led to a persistently high utility return to both domestic debt service and military expenditures. In the context of our model, this implies that the indifference curves in a state of war have smaller gaps between the two segments than indifference curves in times of peace, which will increase the likelihood of a default equilibrium. Such a default equilibrium is illustrated by the corner solution in Figure 4. Second, war may reduce the amount of revenue available to the state. This can happen if, for example, a blockade interrupts trade and therefore customs revenue. A reduction of revenue would shift the budget constraint to the left. This effect would further increase the likelihood of an equilibrium in which the state defaults on its foreign debt. This is because the closer one is to the origin, the smaller are the gaps between the two segments of the indifference curves. Thus, through a relatively higher return to military - or other domestic - spending as a result of the direct demands of war, and/or their related reduction in revenues, war will often be associated with an increased likelihood of government default.

FIGURE 4

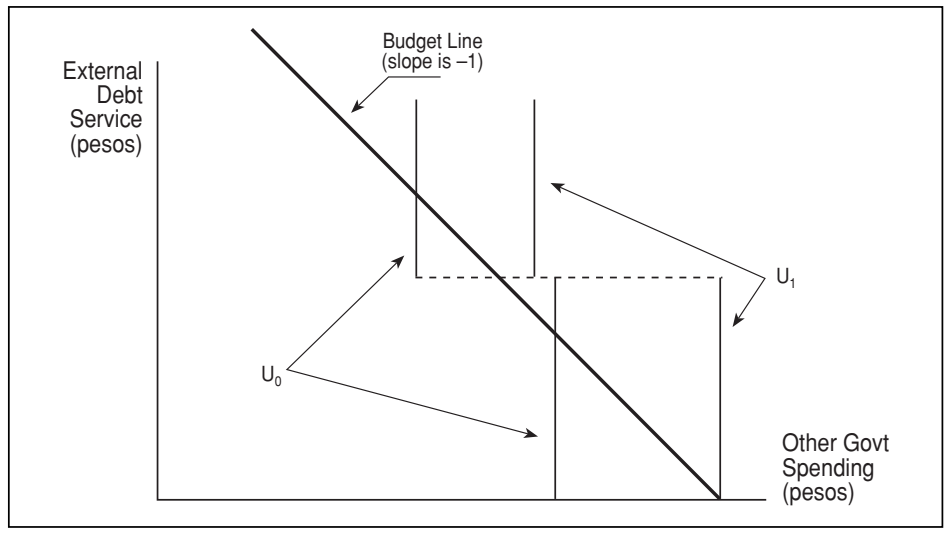


Notwithstanding, there are two countervailing cases in which war could potentially increase the likelihood of debt service. First, as the «sanctions» literature emphasizes, a war that is precipitated by creditor country retaliation for a default obviously raises the utility of external debt service relative to the utility gained from domestic spending. Scholars have overwhelmingly shown, however, that British government intervention on behalf of the bondholders was minimal in our period of study (Mexico is the exception that confirms the rule) ${ }^{15}$. Therefore, we do not anticipate this effect to have played a major role. Second, countries that are in good standing with foreign creditors (the case of Chile since 1842, Peru since 1849 and Argentina since 1857) might prioritize debt service relative to domestic spending if they have access to foreign loans to finance war expenditure. Indeed, we show below that for these countries the negative impact of wars on their respective credit risks dwindles after successful settlement ${ }^{16}$.

\section{STATE FINANCES AND WAR}

In what follows we provide evidence consistent with these insights. However, first it is important to provide some indication of the overall financial burden that external debt service constituted for these countries. Examining the ratio (hypothetical or actual) of external debt service to government revenues gives us a first glance into the likelihood of debt service compliance. From the treasury accounts we were able to construct the ratio of external debt service to government revenue for these countries for some years. These data are presented in Table 5. The debt service ratios for Gran Colombia successor states (New Granada, Venezuela and Ecuador) were the highest, until each of them re-scheduled their debts in the 1840s and 1850s, thereby greatly reducing debt service. Buenos Aires, Chile, and Peru initially had debt service burdens in the twenty per cent range, but these declined due to increased revenues even before those countries resumed payment on their debt. Note that each of these countries resumed payment on the original debt plus capitalized interest arrears, which entailed a greater debt service than originally. Finally, Mexico began the period with the lowest debt service burden, which remained more stable than the others through the period - at roughly ten per cent of government revenues.

There is no clear pattern between debt service ratios and default. Some countries defaulted on their debt in spite of facing relatively low debt service

15 Platt (1968) and Tomz (2007).

16 An in depth discussion of this result is beyond the scope of this paper. Obviously there are a number of potential explanations. Wars might not have affected as significantly their yield spreads because of their economic and/or political fundamentals, because of the specific characteristics of their commitment to repay, or simply because of the specifics of the conflicts themselves. We leave this discussion for further research. 
TABLE 5

RATIO OF EXTERNAL DEBT SERVICE TO GOVERNMENT REVENUE

\begin{tabular}{|l|c|c|c|c|c|c|c|c|c|}
\hline \multicolumn{1}{|c|}{ Country } & $\mathbf{1 8 2 5 -}$ & $\mathbf{1 8 3 1 -}$ & $\mathbf{1 8 3 6 -}$ & $\mathbf{1 8 4 1 -}$ & $\mathbf{1 8 4 6 -}$ & $\mathbf{1 8 5 1 -}$ & $\mathbf{1 8 5 6 -}$ & $\mathbf{1 8 6 1 -}$ & $\mathbf{1 8 6 6 -}$ \\
$\mathbf{1 8 3 0}$ & $\mathbf{1 8 3 5}$ & $\mathbf{1 8 4 0}$ & $\mathbf{1 8 4 5}$ & $\mathbf{1 8 5 0}$ & $\mathbf{1 8 5 5}$ & $\mathbf{1 8 6 0}$ & $\mathbf{1 8 6 5}$ & $\mathbf{1 8 7 0}$ \\
\hline Buenos Aires & 0.21 & 0.14 & 0.18 & 0.11 & 0.09 & 0.09 & 0.09 & 0.05 & \\
\hline Chile & N.A. & 0.18 & 0.13 & 0.12 & 0.13 & 0.09 & 0.08 & 0.14 & 0.09 \\
\hline Ecuador & N.A. & 0.64 & 0.53 & N.A. & 0.44 & 0.44 & 0.05 & 0.05 & 0.05 \\
\hline Gran Colombia & 0.29 & N.A. & N.A. & N.A. & N.A. & N.A. & N.A. & N.A. & N.A. \\
\hline Mexico & 0.10 & 0.11 & 0.09 & 0.06 & 0.13 & 0.13 & 0.15 & N.A. & N.A. \\
\hline New Granada & N.A. & O.44 & 0.44 & 0.34 & 0.06 & 0.15 & 0.24 & & \\
\hline Peru & O.23 & N.A. & N.A. & 0.09 & 0.05 & 0.11 & 0.07 & & \\
\hline Venezuela & N.A. & O.44 & 0.36 & 0.04 & 0.06 & 0.10 & 0.10 & N.A. & N.A. \\
\hline
\end{tabular}

Sources: Amaral (1995), Burgin (1946), Irigoin (2000), Cortés-Conde (1989), Resumen de la Hacienda Pública de Chile, Rodríguez (1985), Memoria de la Hacienda de Colombia, Tenenbaum (1995), Memoria de la Hacienda de Nueva Granada, Tantalean Arbulú (1983), Berglund (1995), Memoria de la Hacienda de Venezuela, Fenn's Compendia.

Notes:

* These are not five-year averages, but selected years in each five-year range. Five-year averages were not possible to calculate because of the lack of data. The dates used for each country are as follows:

Buenos Aires: 1828, 1834, 1837, 1844, 1849, 1851, 1858, 1864. Chile: 1833, 1839, 1843, 1849, 1853, 1857. Ecuador: 1834, 1839, 1847, 1854, 1857, 1863. Gran Colombia: 1825. Mexico: 1827, 1834, 1839, 1842, 1850, 1853, 1860. New Granada: 1832, 1838, 1844, 1847, 1853, 1857. Peru: 1830, 1846, 1850. Venezuela: $1832,1839,1844,1849,1854,1859$.

** Figures in italics denote hypothetical debt service, as the country was in default.

$* * *$ Figures reflect the debt service on new foreign borrowing that occurred after settlement. See table 3 in the appendix.

**** The figures for Ecuador, New Granada and Venezuela prior to their re-scheduling agreements are based upon the partition of Gran Colombia's debt agreed to between 1834 and 1838 .

ratios. In the case of Ecuador's default in 1869, for example, the debt service burden was about five per cent of government revenues, a similar ratio to Venezuela's when it defaulted in 1847. Compared to the debt service ratios of other debtor countries, the Spanish American ratios are relatively low (with the exception of Colombia, Ecuador and Venezuela before their first episodes of debt renegotiation) ${ }^{17}$. Contrary to the widely held view that Latin America's debt burden was unmanageable from the start, the data suggest that none of these countries were condemned to remain in default due to an intractable foreign debt burden. We now turn to examine the Treasury records in order to provide some insight on the effects of warfare on the fiscal finances of these countries.

17 They compare relatively well with Brazilian ratios, which fluctuated between 15 to 45 per cent. The ratios of debt service to total taxes in eighteenth century France and Great Britain were around 40 to 50 per cent. See Summerhill (2008, p. 10). 


\subsection{Military expenditures during war}

The military costs of wars could wreak havoc on any plans to service the foreign debt. One can compare the trend of military expenditures and total expenditures for the various countries in the panels of Figure 5. Examination of the records of the Treasury ministries indicates that the military expenditures averaged about $1 / 3$ of total government expenditures over the period. Military expenditures tend to rise substantially during wartime, reaching maxima of nearly $3 / 4$ of expenditures during major wars. These are likely underestimates, because data are often missing during the years with the most serious conflicts. For example, data from the Treasury are missing during Ecuador's wars in 1833, 1845, 1852, and 1859-1860. Venezuelan and New Granadan data during the height of their civil wars are either missing or incomplete. Peru's Treasury did not publish an annual report between 1832 and 1845 . The Mexican case is particularly instructive. There are several spikes in the military expenditures series: corresponding with the Federalist Revolt of 1832, the Texas War of 1835-1836, again in 1838-1841, and just

FIGURE 5

SPANISH AMERICAN FISCAL HISTORIES

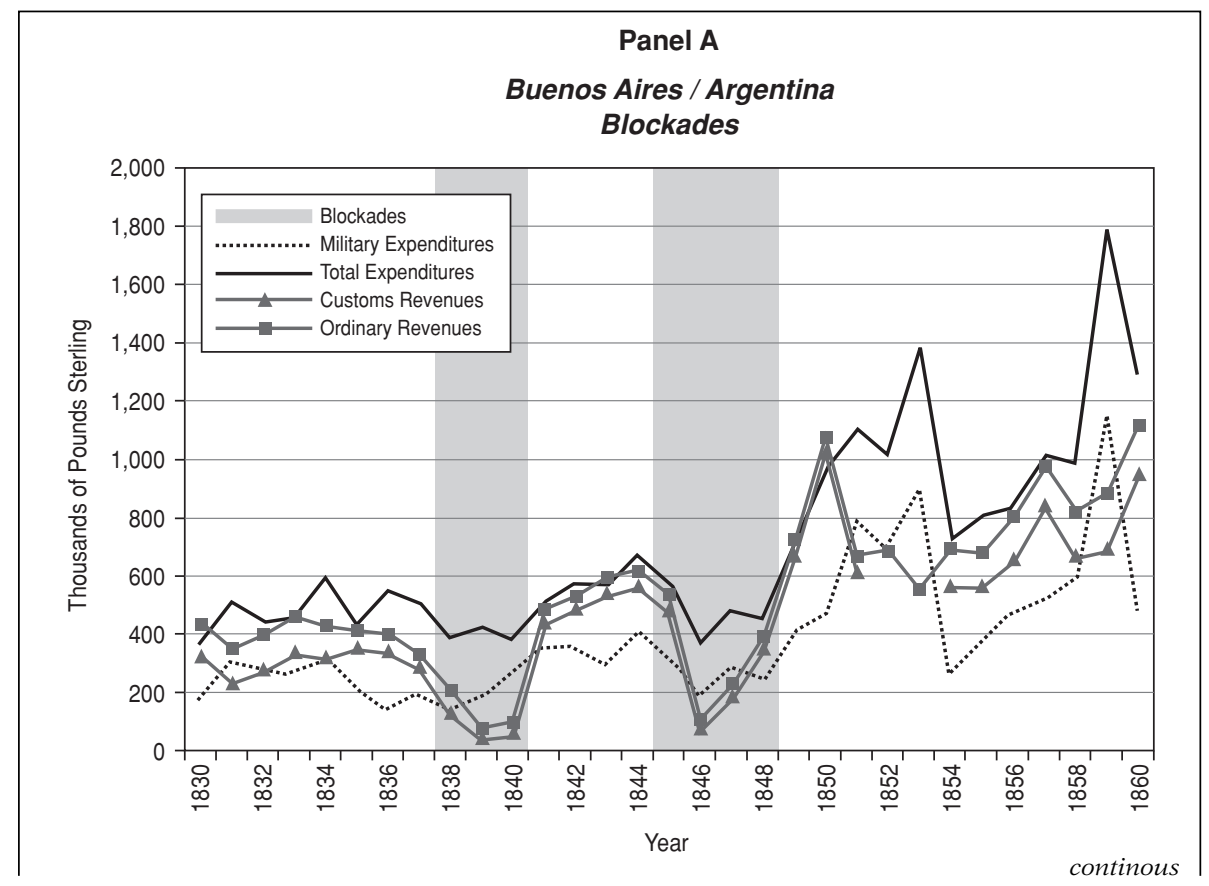


continuation

Panel B

Buenos Aires / Argentina

Wars

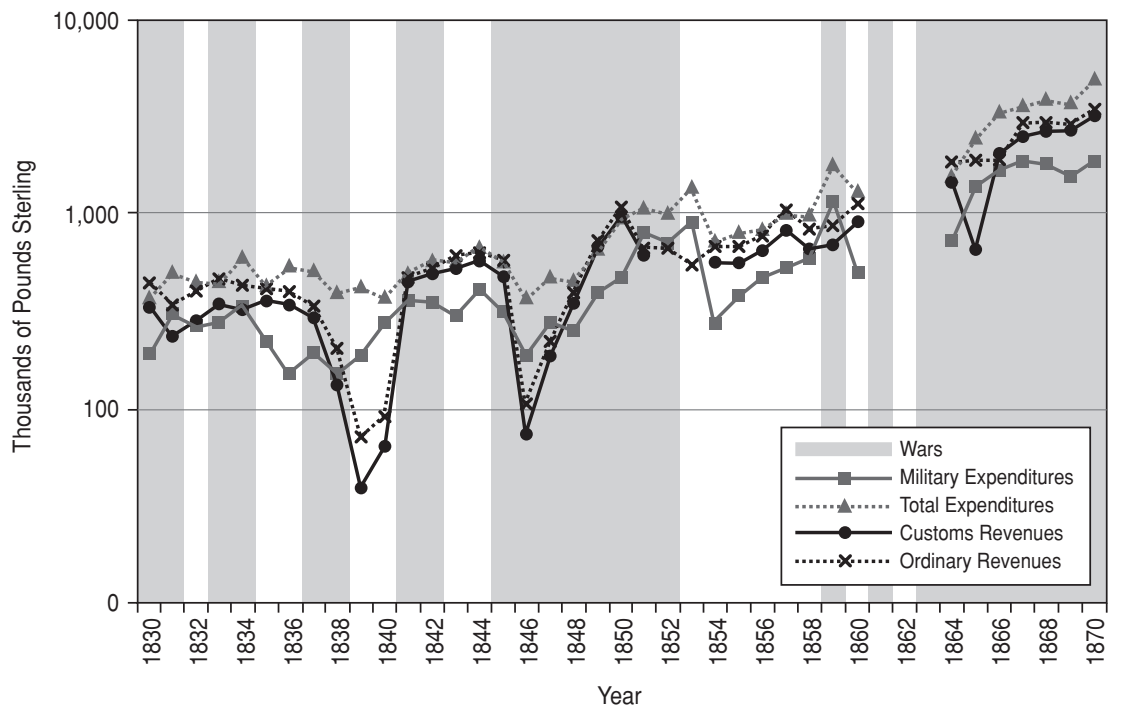

Panel C

Chile

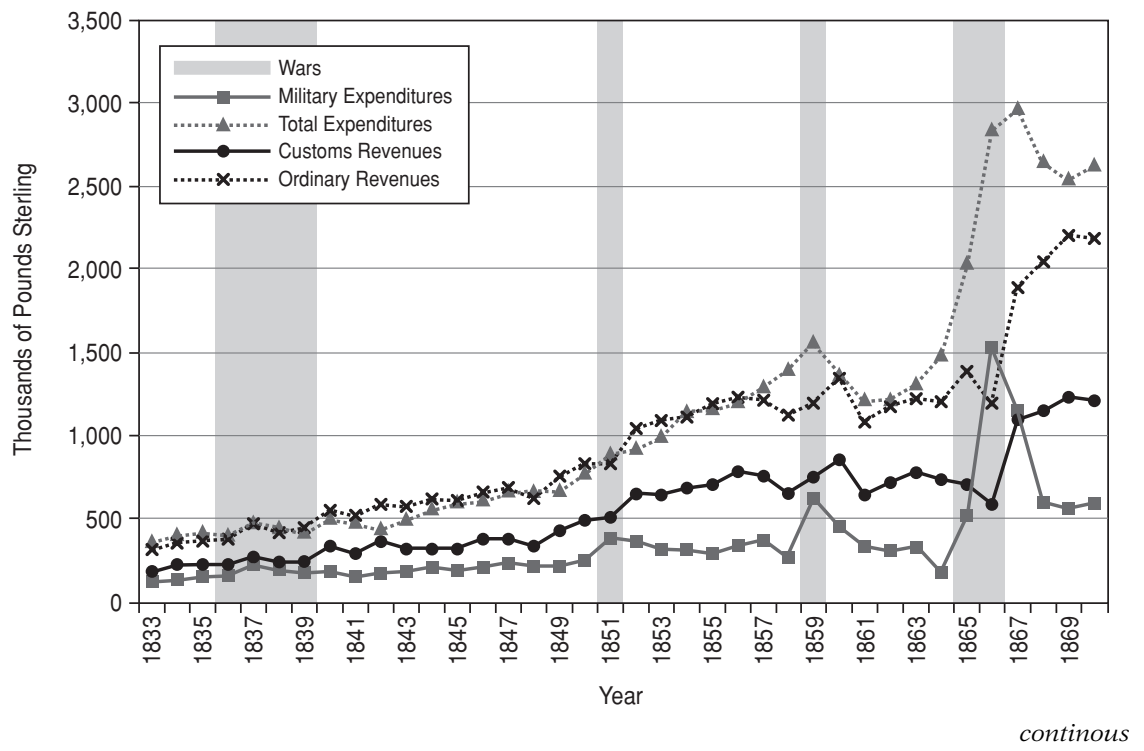




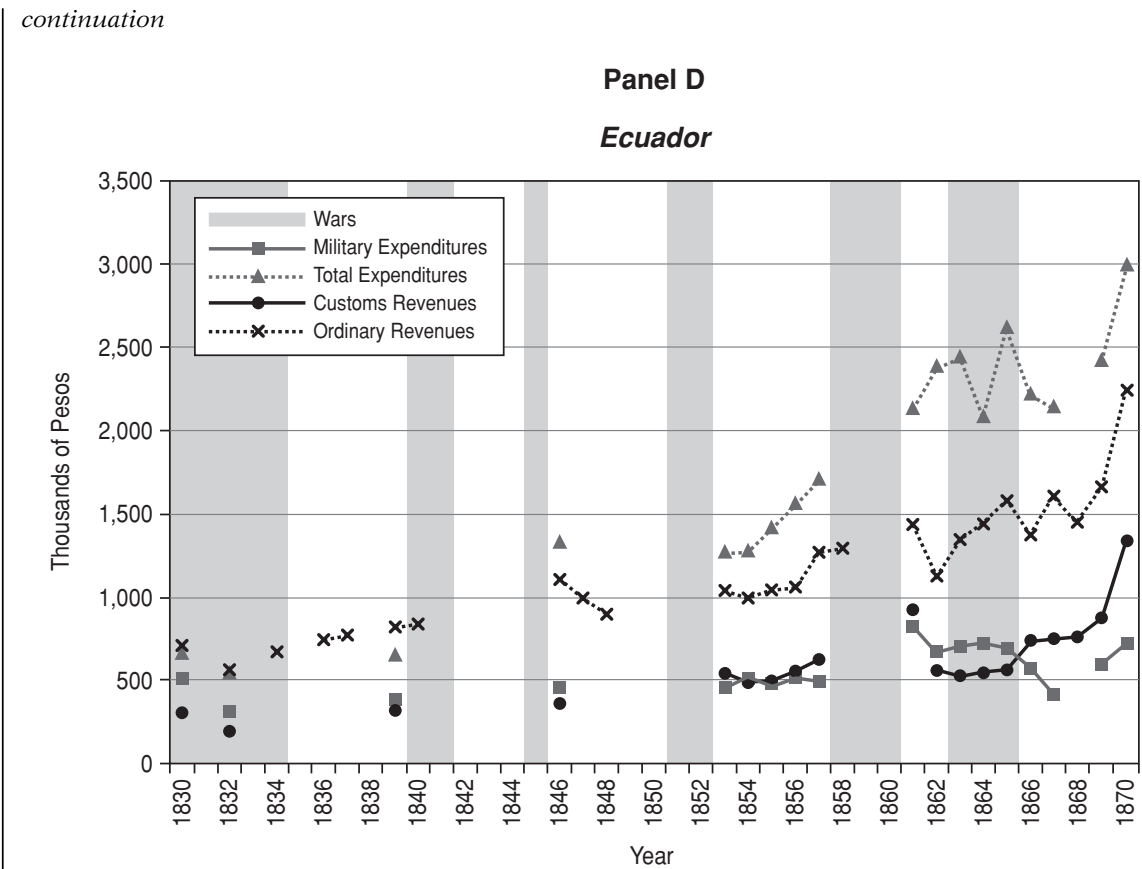

\section{Panel E}

Mexico

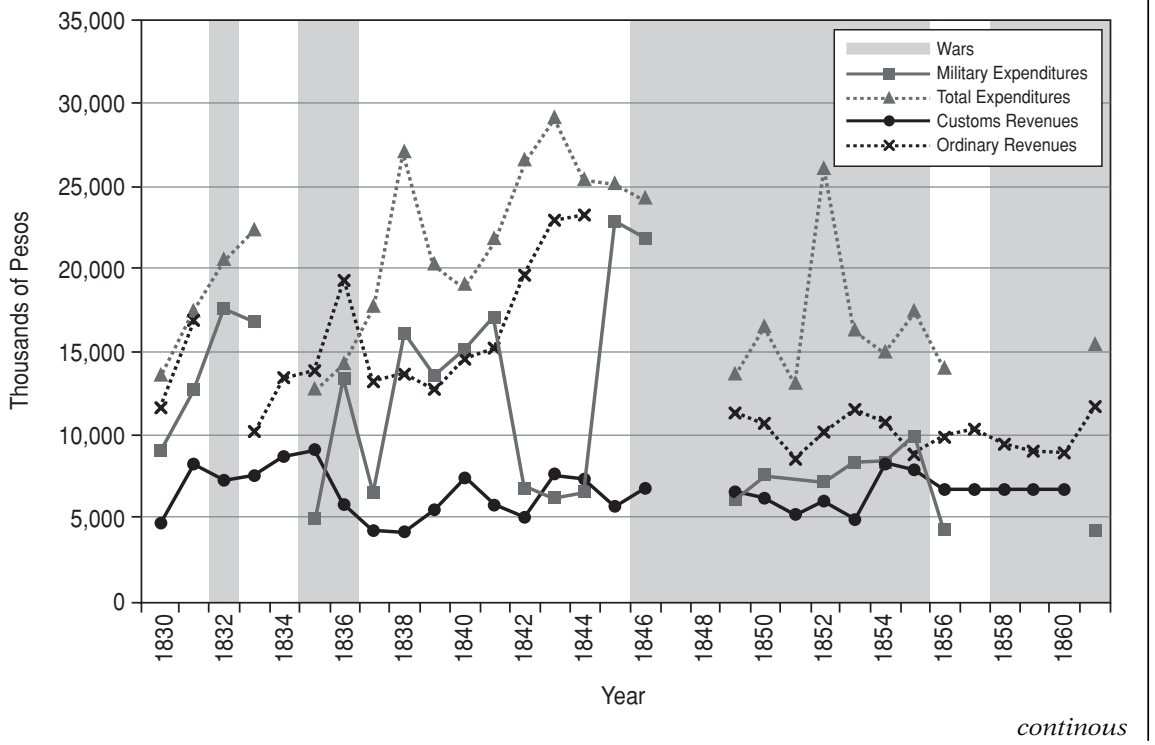


continuation

Panel F

New Granada / Colombia

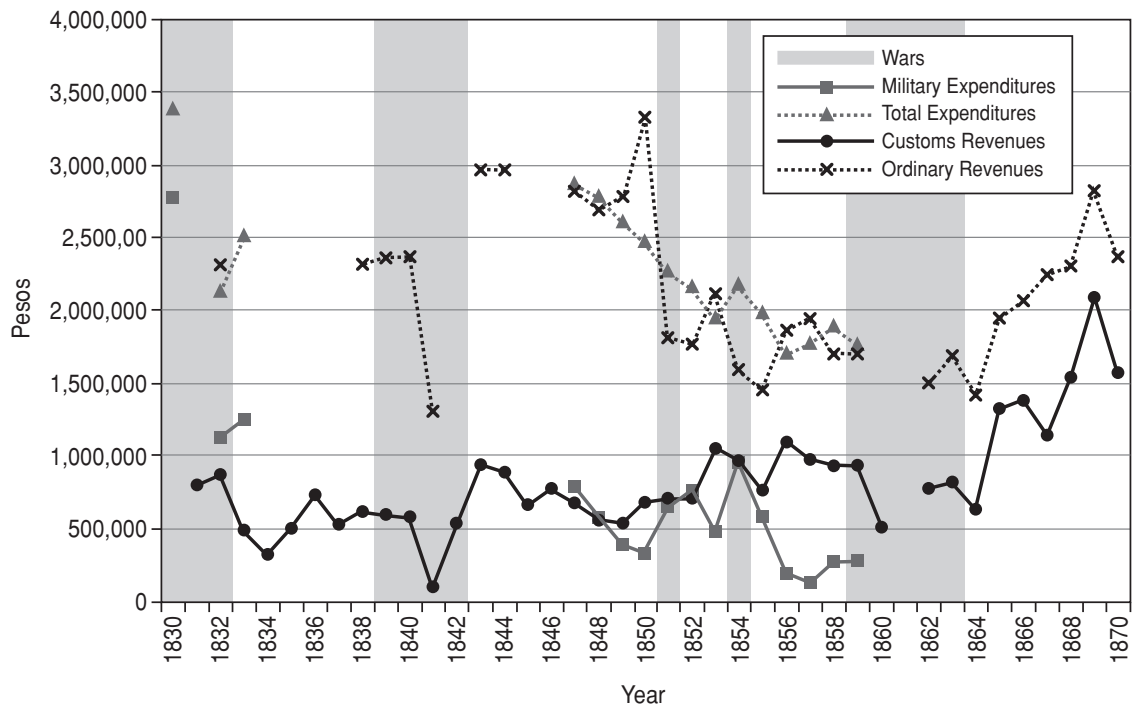

Panel G

Peru

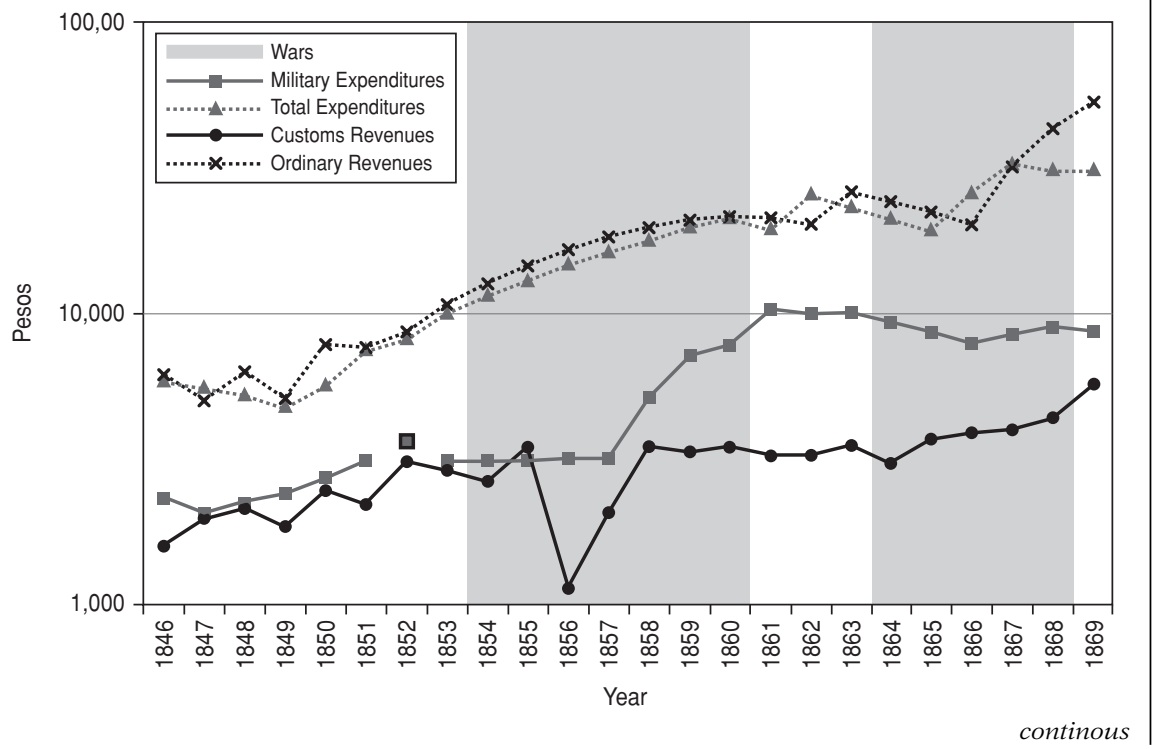




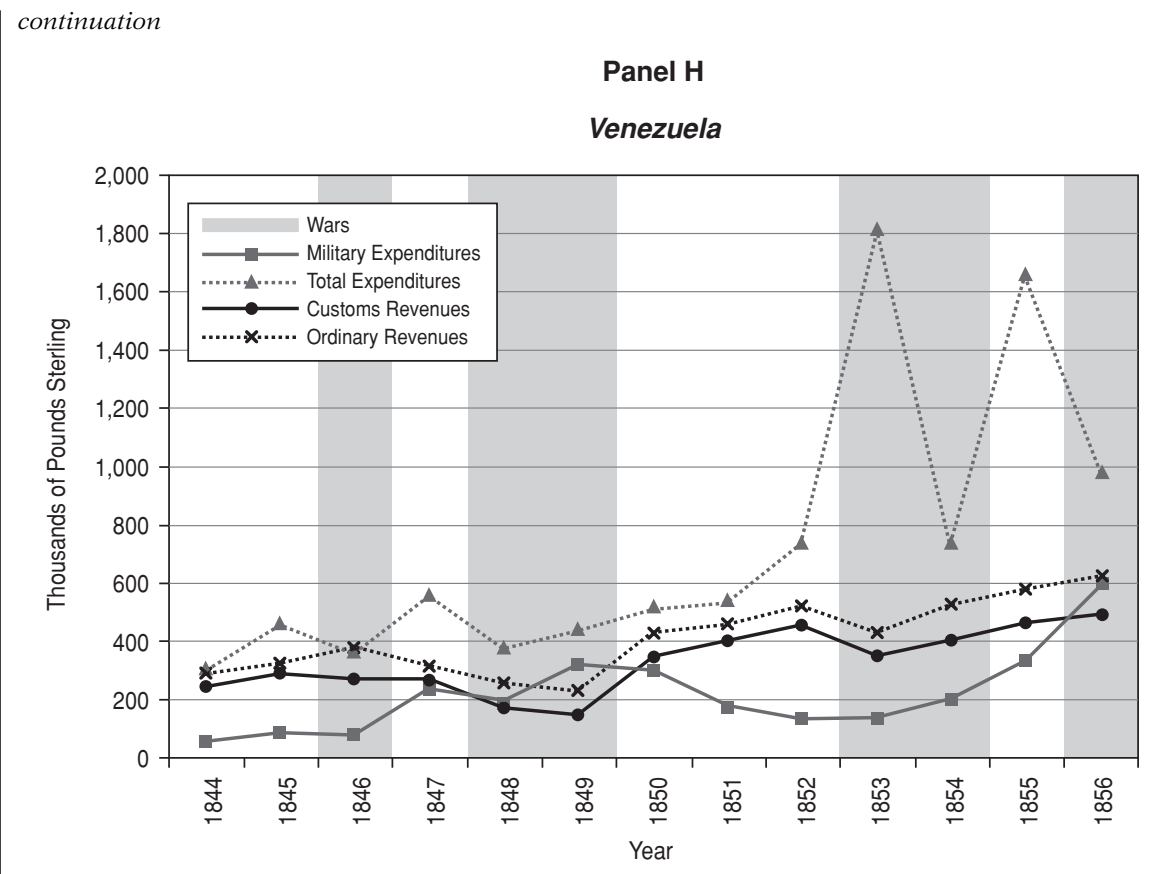

Sources: The Course of Exchange and the Economist.

Note: We used the Gleditsch-Correlates of War criteria for Buenos Aires/Argentina and Mexico, and we used the alternative criteria for the other countries.

prior to the U.S. invasion. Total expenditures peak in 1852, but this is due to the disbursement of proceeds from the U.S. war indemnity. Military expenditures rise again during the Ayutla Revolt of 1854-55. But just as significant is the complete absence of expenditures data for the height of the U.S.Mexican War, and for the internal War of the Reforma. These wars were immensely costly and disruptive of the Treasury. One indicator of the disruption is that there were twenty-nine changes at the head of the Treasury Ministry in the thirty-six months from January 1846 to December $1848{ }^{18}$. Aside from missing data, in some cases like that of Venezuela, there is every reason to believe that the Treasury accounts for military expenditures are dramatically understated (see Berglund, 1995).

18 Stevens (1991, p. 11). 


\subsection{Revenue during war}

The ability to raise revenue through taxation was notoriously weak in early republican Spanish America. Scholars have emphasized weak administrative structure, lack of political will to tax the property of the landed elites, and general poverty as reasons for the inability of the central governments to collect significant revenues in the form of taxes ${ }^{19}$.

Figure 5 shows that some countries were able to increase ordinary revenues during war, a notable example is Chile, but revenues usually fell during conflict. The figure also shows the predominance of customs revenues, usually accounting for over half of total ordinary revenues. Customs was the easiest tax to collect because the revenue was collected at geographic bottlenecks for the transit of commerce. This factor made customs also easy to attack. Naval blockades stand out as a key factor in the explanation of some of the most drastic reductions in revenues during wars. Most of the countries in our study had one or two major ports that accounted for an overwhelming portion of the traffic. In Mexico, it was Veracruz and Tampico; in Ecuador, Guayaquil; in Peru, Callao. But perhaps none of the debtors was more reliant on customs than Buenos Aires. Panel A of Figure 5 shows the trend of customs revenues, total revenues, military expenditures and total expenditures in Buenos Aires for the years 1830-1861 ${ }^{20}$. Years in which there was a naval blockade are highlighted. The dominance of customs for revenue, and military for expenses is clear. What is most striking, however, is the degree to which the blockades of the late 1830s and the mid 1840s affected revenues and the budget deficit. The government financed the deficit by issuing currency, causing the value of the paper peso to plummet (Burgin, 1946; Irigoin, 2000).

There are other illustrative examples of the importance of blockades. When Peru blockaded Guayaquil for ten months beginning in 1858, it completely cut off trade and led directly to Ecuador's default ${ }^{21}$. Although trade rebounded, and with it customs revenues, Ecuador remained in arrears until it repudiated the 1855 settlement in 1869 . In short, the naval blockade was a potentially potent and debilitating tool of war at the time, which dramatically affected governments' debt service decisions.

\subsection{Emergency debt accumulation during war}

Figure 5 clearly shows that wars coincided with burgeoning budget deficits, spurred on by increased military expenditures and, often, decreased

19 See Centeno (2002), Deas (1982), Gootenberg (1996), Jaramillo, Maisel, and Urrutia (2001), Marichal and Carmagnani (2001), Rodríguez (1985) and Tenenbaum (1995).

${ }^{20}$ Throughout the paper, when possible, we present all figures converted to British pounds sterling. The figures are not deflated, as reliable price indices do not exist in every case.

${ }^{21}$ Fenn (1867, p. 289). See also Terán (1896). 
revenues. With the exception of Chile, Peru and Argentina when those countries borrowed abroad, the main means for covering the deficit was domestic borrowing. Domestic emergency credit took many forms. Governments often fell behind in paying civil servants, and even in some cases the military. There were also forced and unforced loans from merchants, mortgages of different "ramos» of the treasury, and government bond issues. These debts, which ballooned during wartime, were serviced piecemeal for years thereafter. For example, Venezuela was plagued by frequent rebellions beginning in the late 1840s. By 1856, it had so institutionalized domestic debt rollover that the treasury's division in charge of it, known as the "Ramo de Liquidación» (or Solvency Branch), accounted for 75 per cent of total (ordinary plus extraordinary) government revenues. The largest claimants, together making up 63 per cent, were the «acreedores corrientes» (principally unpaid salaries), and the "acreedores por contrato" (merchant loans) ${ }^{22}$. The accounts detail a bewildering array of short-term emergency credit operations.

The case studies by Berglund (1995), Deas (1982), Gootenberg (1996), Halperin Donghi (1982), and Tenenbaum (1986) show that although foreign resident merchants provided the funds for some of the revolving debt, most was domestically financed. For most countries, reliable data series on the size of the domestic debt and domestic debt service do not exist. There are some series, however, that provide indications of the dimensions of domestic debt accumulation. According to Quiroz (1995), Peru's domestic debt more than quintupled between 1830 and 1845, exceeding one million pounds sterling. Peru was at war during ten of those years. Tenenbaum's (1995) series of domestic loans in Mexico show enormous increases during the war of Texas' secession, and during the French blockade in 1839. In both instances domestic loans accounted for over thirty per cent of total government revenues. The most significant increase in Chilean internal debt from independence to 1870 occurred precisely during wars, on the one hand with Peru and Bolivia in the 1830s, and against Spain in the 1860s (Mamalakis, 1978).

The chaos that often accompanied the severe conflicts meant that it could take several years for the Treasury to even become aware of the full scale of the new debts, and regain financial footing. A good illustrative example is that of New Granada. In 1845 the Treasury of New Granada was just starting to get a handle on the financial effects of the War of the Supremes, which ended in 1842. In its 1845 Treasury Report the accounting for the war starts to emerge. The minister explains that in 1840 and 1841 there were decreed forced loans, voluntary loans, and fines on the rebels, and that in 1843 much of those funds finally made it to Bogota. He also suggests that they paid interest on the domestic debt in 1844 . He then enumerates the types and rough

\footnotetext{
${ }^{22}$ Memoria de la Hacienda de Venezuela, 1857.
} 
estimates of the debt accrued during the war. These include back pay for Hacienda employees ( 100,000 pounds) and the military (33,000 pounds), treasury bills emitted to cover missed coupons on domestic bonds $(15,000$ pounds), forced loans (32,000 pounds), debt to Ecuador for assistance provided (20,000 pounds), debt to tobacco planters (30,000 pounds), and for contracts with private firms and individuals (in excess of 100,000 pounds). Ironically, one of the private creditors is the British firm of Powles, Illingworth and Co., the agents for the British bondholders, who in 1841 loaned the government 25,000 pounds at an interest rate of six per cent. About one half of the war debt had been paid back by January 1845, leaving about 240,000 pounds of special debt still to pay, over and above the domestic debt pre-dating the war. These debts, most of which were from the Gran Colombian domestic debt, plus the unpaid interest on them, amounted to about two million pounds sterling. They carried interest of between zero and six per cent.

Prior to the beginning of the war, New Granada had representatives in London in discussions with foreign bondholders, at the same time as representatives of Venezuela (Committee of Spanish American Bondholders, 1840). The proposed settlement was scuttled because of the war. In his 1844 report to Congress, the Treasury Minister wrote,

«Despite the sincere desires of the government to conclude a satisfactory agreement with foreign creditors and on the part of New Granada, nothing has been done about the matter and things remain in the same state as they were at the end of the last Congressional session... Although the President is fully authorized to arrange for payment taking necessary funds from the national revenue, it is also true that a substantial debt weighs on those revenues, a debt that was contracted for the maintenance of constitutional government during the last war, and for the satisfaction of that debt the richest branches of the treasury are especially mortgaged. If it were to deduct from these funds a considerable sum for paying the foreign debt, the credit of the nation would not advance, what would be gained abroad would be lost at home, and if unfortunately the revolutionary occurrences that have caused such enormous damage to the Republic should repeat themselves, the Government would not be able to find anyone to lend it money».

In sum, New Granada presents an example of a country heavily burdened by debt, accruing extraordinary expenses during war, funding them by emergency measures, and giving preference to emergency creditors over external bondholders for clearly articulated political reasons. Other examples abound. In the course of eleven years (1840-1851) Rosas paid off the Buenos Aires domestic debt of over fifty-four million pesos, leaving the external debt in 
default untouched ${ }^{23}$. The Peruvian merchant elite only endorsed the Peruvian debt settlement after the consolidation of the domestic debt was well under way in 1849. A number of foreign loans received by the Peruvian government in 1853 were famously earmarked for the conversion of a massive portion of the domestic debt into external debt ${ }^{24}$.

For some countries, at times the debt burden was so great that the service of many domestic debts was suspended. The frequent revolutions in Venezuela from 1846 to 1856 led to a series of emergency loans (see their effect on the budget in Panel $\mathrm{H}$ of Figure 5). The peaks in military spending and widening government budget deficits correspond clearly with wars. Note that because Venezuelan fiscal years were from July 1 to June 30, there is a lag in the effect of some of the wars. The very large increases in total expenditures in the early 1850s reflect attempts to consolidate the debt, and, according to Berglund (1995), military-related expenses as well. The Treasury Minister of Venezuela pleaded with Congress in early 1857, just after another revolution, to rein in spending, so that they could properly serve their debts. If they did not, he said, the government would be forced to serve its domestic creditors selectively, which would cause widespread discontent and fuel another revolution. In 1847 the domestic debt was about 325,000 pounds sterling, and consisted mostly of long-term bonds inherited from Gran Colombia. By 1858, the domestic debt had reached a size nearly equal to the foreign bonds: about 3.5 million pounds sterling (22.2 million pesos), while the external debt was at that time nearly 4 million pounds including interest arrears since 1848 . The most serious civil war since independence then broke out, but the Treasury was already in what the minister described as «chaotic conditions». Local loans were being offered only at an interest rate of 1.5 per cent monthly, for full payment in 20 months, and with a mortgage of 50 per cent of customs. Only at this juncture did the government go to London to try to arrange for a settlement and a new foreign loan ${ }^{25}$.

In sum, the evidence from the Treasury clearly shows that wars led to developments in the fiscal sphere that negatively impacted the capacity of coun-

${ }^{23}$ Platt (1983, p. 30).

${ }^{24}$ See Quiroz (1987).

${ }^{25}$ Berglund (1995, p. 445), Eastwick (1868). This was forthcoming in 1862, issued by Barings, only after arrangements were made for the bondholders of the original bondholders, whose 1859 settlement had fallen immediately into arrears. Venezuela maintained payments for just enough time to take out a further foreign loan in 1864. Both loans caused quite a scandal in London financial circles, and Venezuela defaulted on each in sequence over the next three years. Edward Eastwick, who negotiated the 1864 loan on behalf of the bank, General Credit, blamed the English government, which, he said, "gratuitously parades its determination not to enforce the claims of its subjects. Now, whatever the intentions of a claimant may be, it is surely very unwise to proclaim beforehand that resort will not be had to ulterior measures. It is like putting up a board to warn trespassers that they will not be prosecuted» (Eastwick, p. 328). The case of Venezuela's access to foreign credit despite its poor record of debt service is the exception among the countries in our study. 
tries to service their foreign debt. Faced with increased military expenditures, and the need to satisfy domestic emergency creditors, we provided examples of countries in default that delayed settlement, and others that were servicing their debts and chose to default. In what follows we examine how investors in Spanish American sovereign debt incorporated news about war into their behavior in the London bond market.

\section{WARS AND THE BOND MARKET}

From letters to The Times of London, investor reports in Fenn's Compendia, as well as publications of the Committee of Spanish American Bondholders, and later Corporation of Foreign Bondholders, it is clear that the investing public was tuned into political and military developments abroad. Investors would factor in their views on the likelihood of repayment when determining their willingness to pay for the bonds in question, and thus their cumulative views should be observable in bond prices ${ }^{26}$.

Figure 6 presents the prices of each country's bonds during the years 18301869 , and shades in the years in which there were wars ${ }^{27}$. In order to take into account the fluctuations of the market, as well as examine a measure of the risk premium of these securities, we calculate the spread between the yield of the Spanish American bonds and the yield of the British Consol. These are presented in Figure 7. Note that these are informal definitions of "yield», since there were no dividends paid for countries in default.

The diagrams provide strong evidence that across Spanish America, wars are generally associated with lower bond prices (higher yield spreads). Not all wars had equal impacts, and some countries appeared to have had wars with more significant bond market effects than other countries did. Especially large effects are notable in the case of Mexico, whether it be during the internal conflicts of 1832 and the 1850s or during the wars over Texas and the U.S.-Mexican war of the late $1840 \mathrm{~s}^{28}$. Mexico is also noteworthy because of two apparent anomalies - the steep rise in bond prices in the late 1840 s and in the 1860s- The former is associated with the U.S. indemnity payment, of which a portion was earmarked for bondholders, a key ingredient in the partially successful settlement of 1850 (Tenenbaum, 1986; Bazant, 1968). The latter is associated with the French invasion that installed

${ }^{26}$ For a recent assessment of the relative importance of wars on credit risk see Flandreau and Zumer (2004). The authors find that wars had a negative impact on credit worthiness during the first wave of globalization 1880-1913.

27 Bond price data are from Course of the Exchange and the Economist.

28 Fowler (2000), who offers a revisionist interpretation of Mexico's internal conflict during this period, believes that most are overblown, and that they had relatively little impact. He makes two exceptions: the 1832 revolt and the 1854-55 Ayutla Revolt, which he says were the only ones that truly had national implications and involved large segments of the population. 


\section{FIGURE 6}

SPANISH AMERICAN BOND PRICES

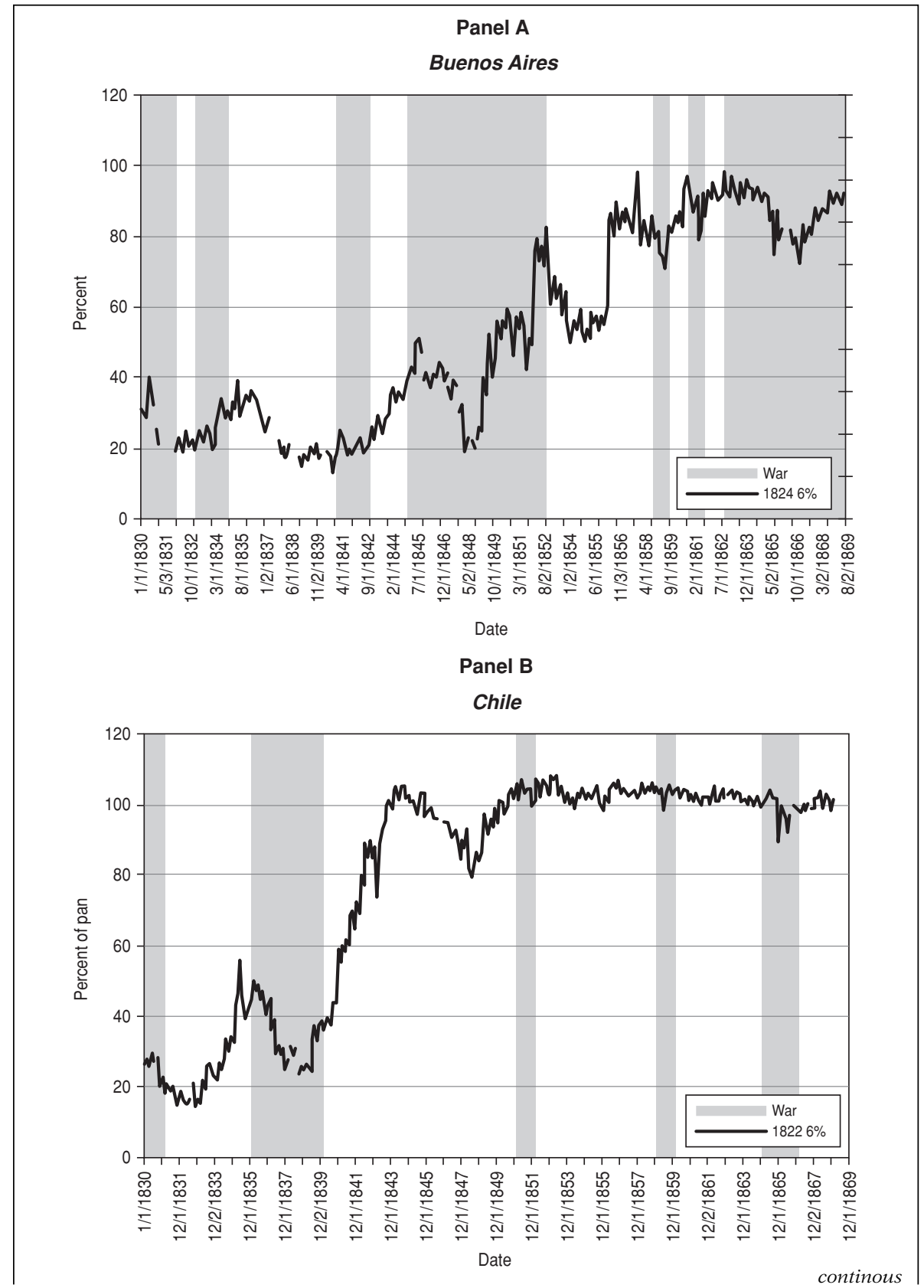


continuation

Panel C

Ecuador

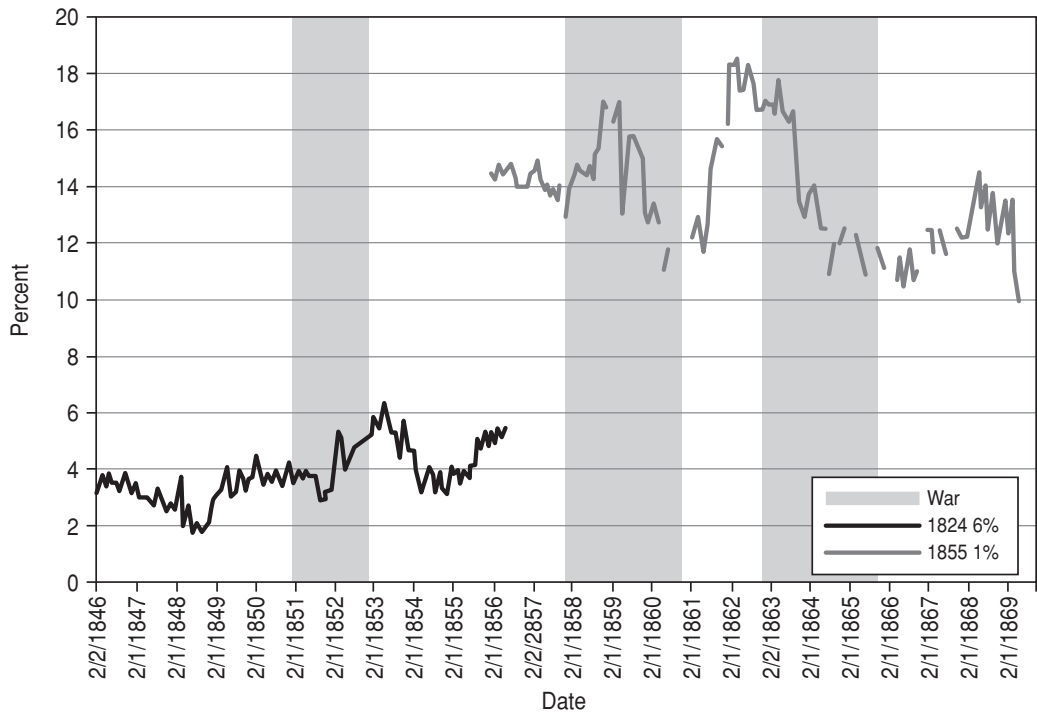

Panel D

Mexico

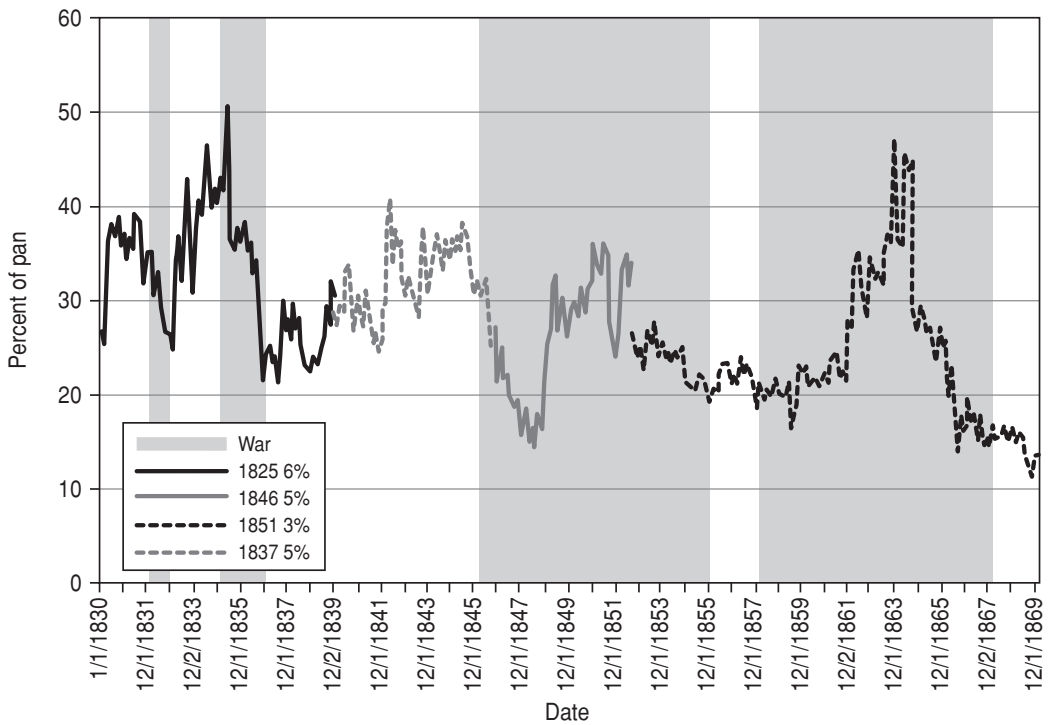

continous 


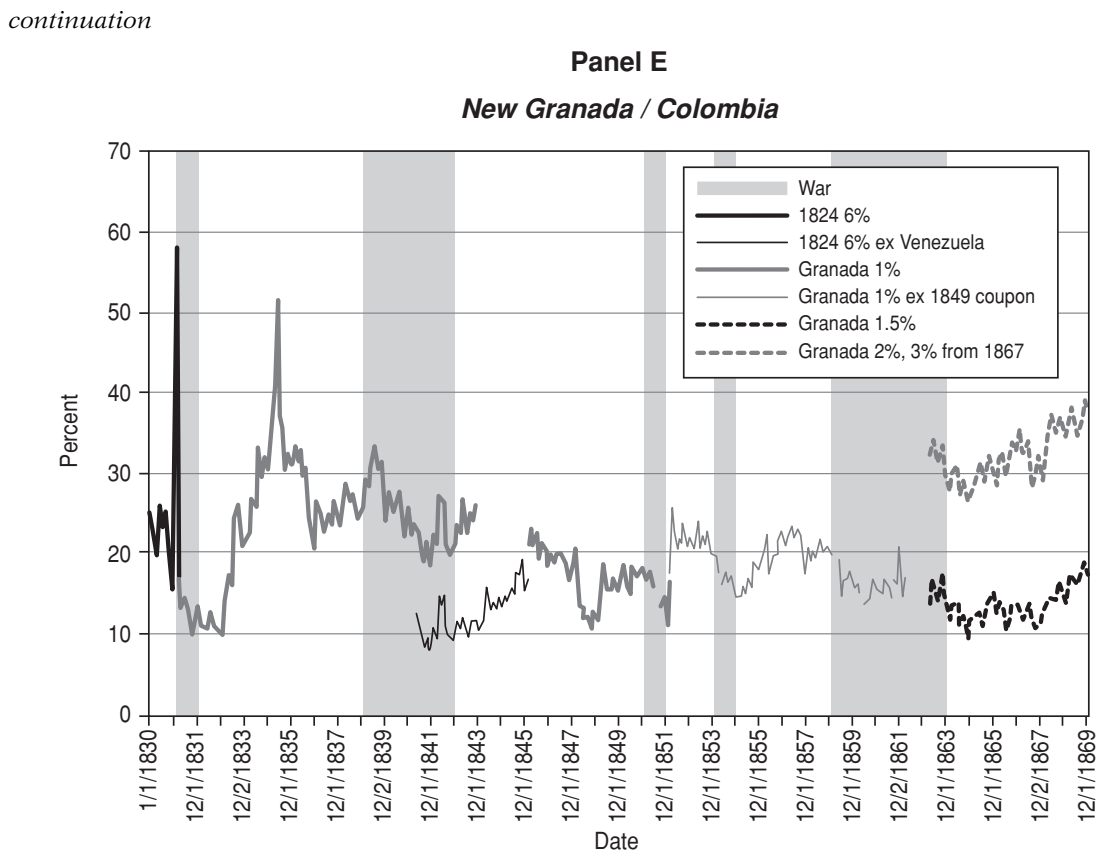

\section{Panel F}

Peru

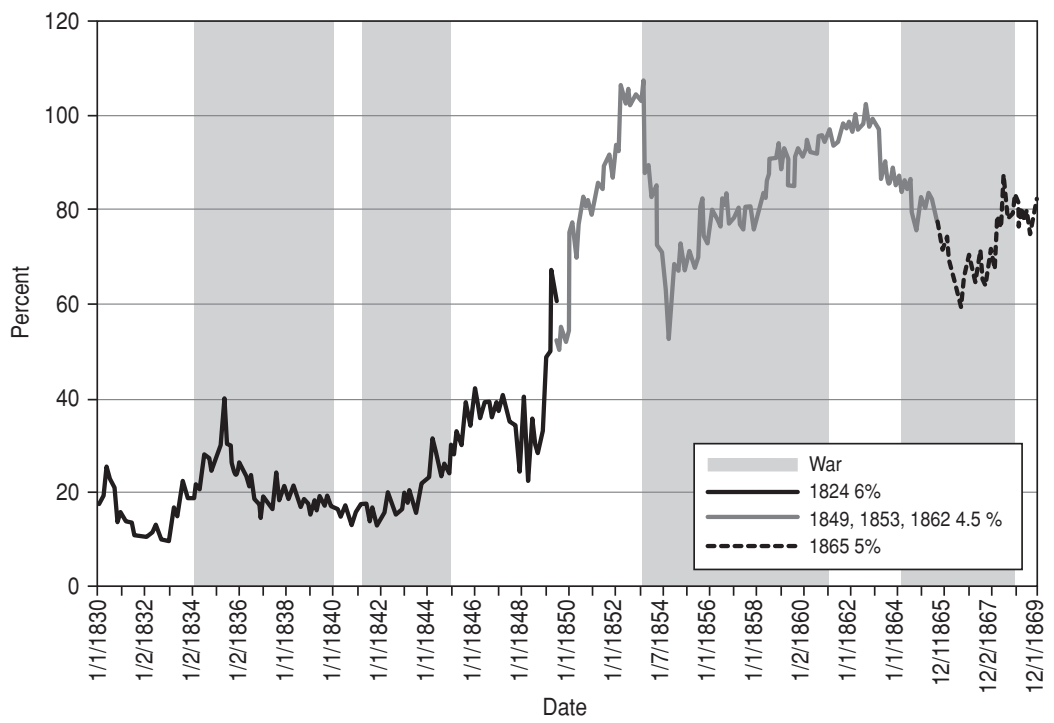

continous 


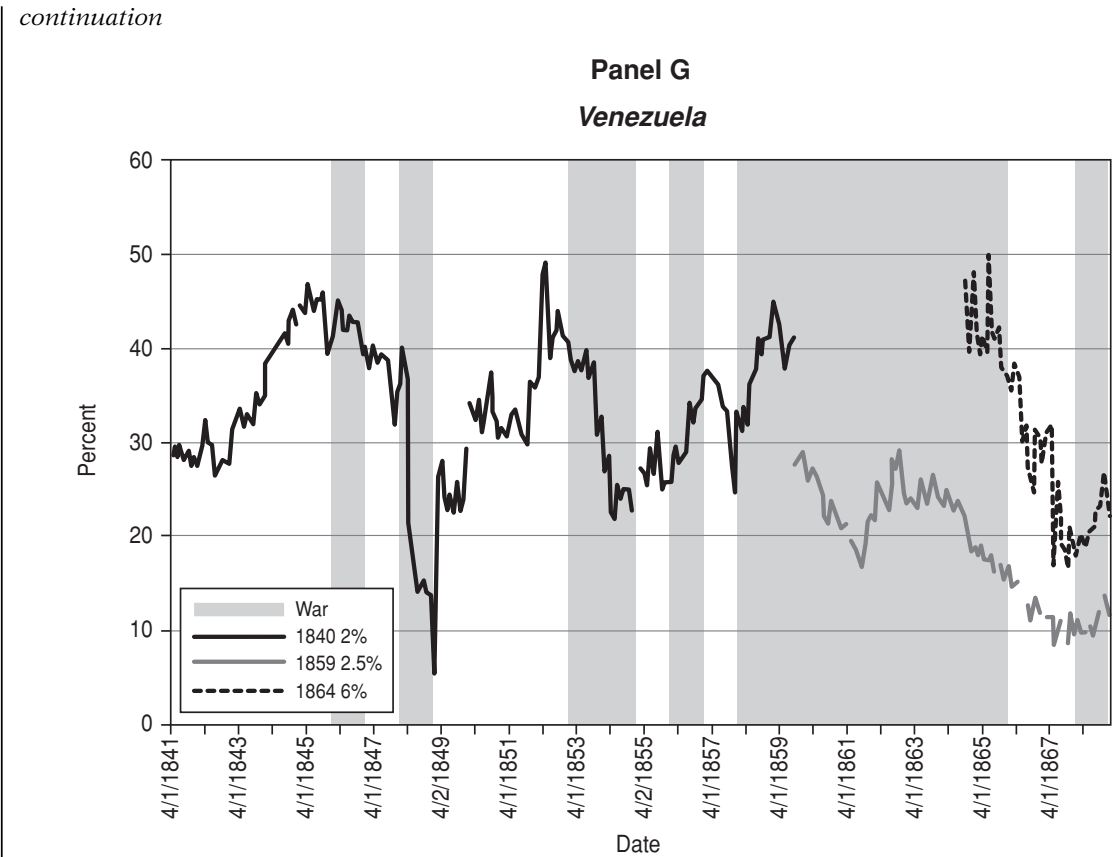

Sources: Course of the Exchange and the Economist.

Note: We used the Gleditsch-Correlates of War criteria for Buenos Aires/Argentina and Mexico, and we used our alternative criteria for the other countries.

Maximilian as emperor ${ }^{29}$. The initial reaction in London to the French invasion and the commitment by the emperor to service the Mexican debt was very positive. As the Mexicans began to gain the upper hand, the yield spread rose back to levels not seen since the U.S.-Mexican War.

In other countries, major effects are also clear: Venezuela in 1847, 1853 and during the Federal War; New Granada during its sequence of civil wars; Chile and Peru during their war in the 1830s; Ecuador during its wars of the late 1850s and early 1860s; and Buenos Aires in the 1830s and 1850s. The case of Ecuador is interesting in that its new bonds issued according to the

29 The French invasion was preceded by a series of events in 1860-1861 that were intimately involved with the foreign debt. A dispute over claims culminated in a mid-1861 announcement that Mexico would begin a two-year moratorium on all foreign debt payments. This was ostensibly the rationale for the French invasion. Platt has argued that Britain did not pursue a policy of military intervention for bondholders during this period, which is backed up by a memorandum by the British Foreign Secretary, Lord Palmerston, and much correspondence published in a special volume of the Sessional Papers (Great Britain, 1847), and the perceptions of bank agents (e.g., Eastwick, 1868). 
FIGURE 7

SPANISH AMERICAN YIELD SPREADS VERSUS CONSOL

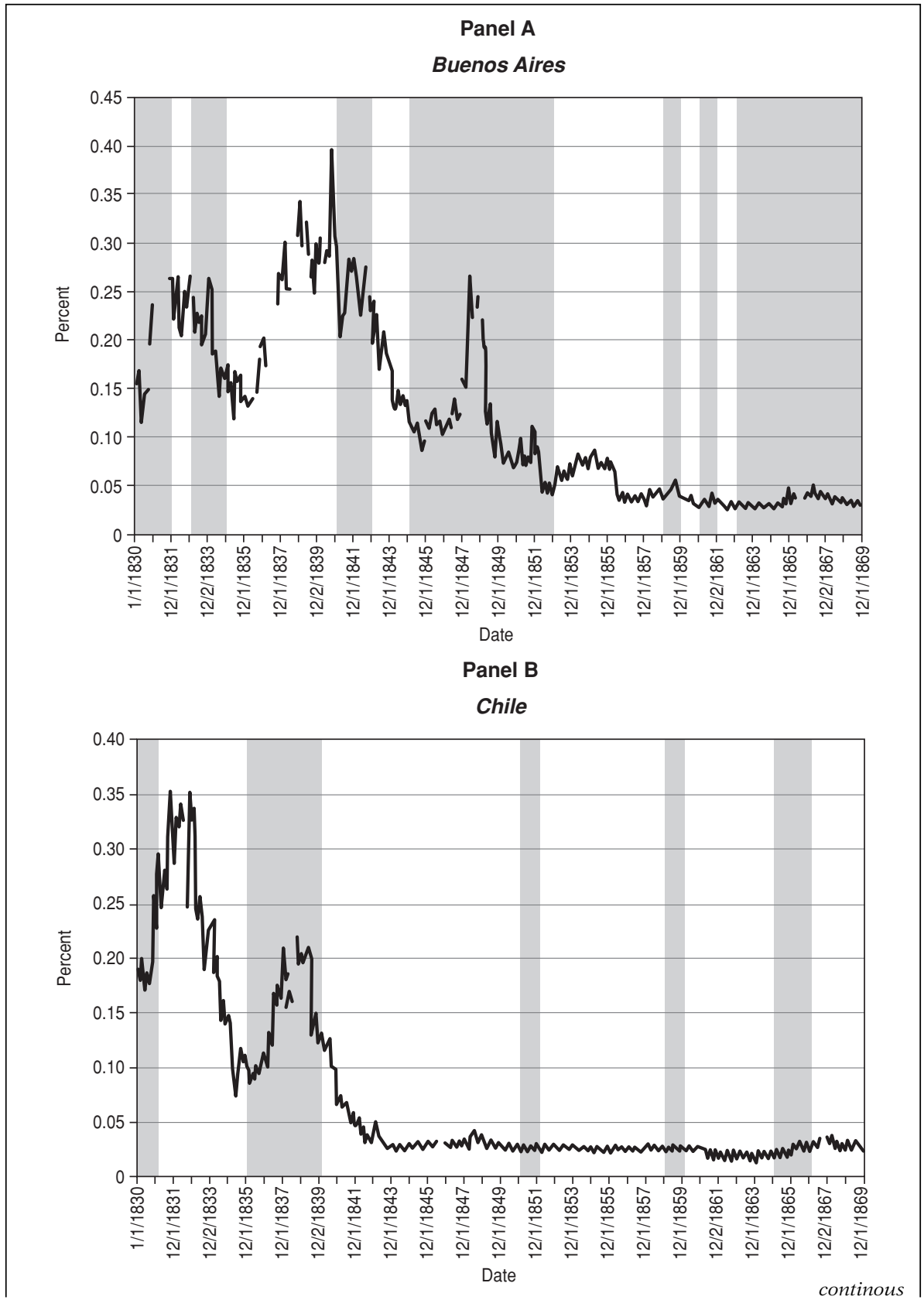




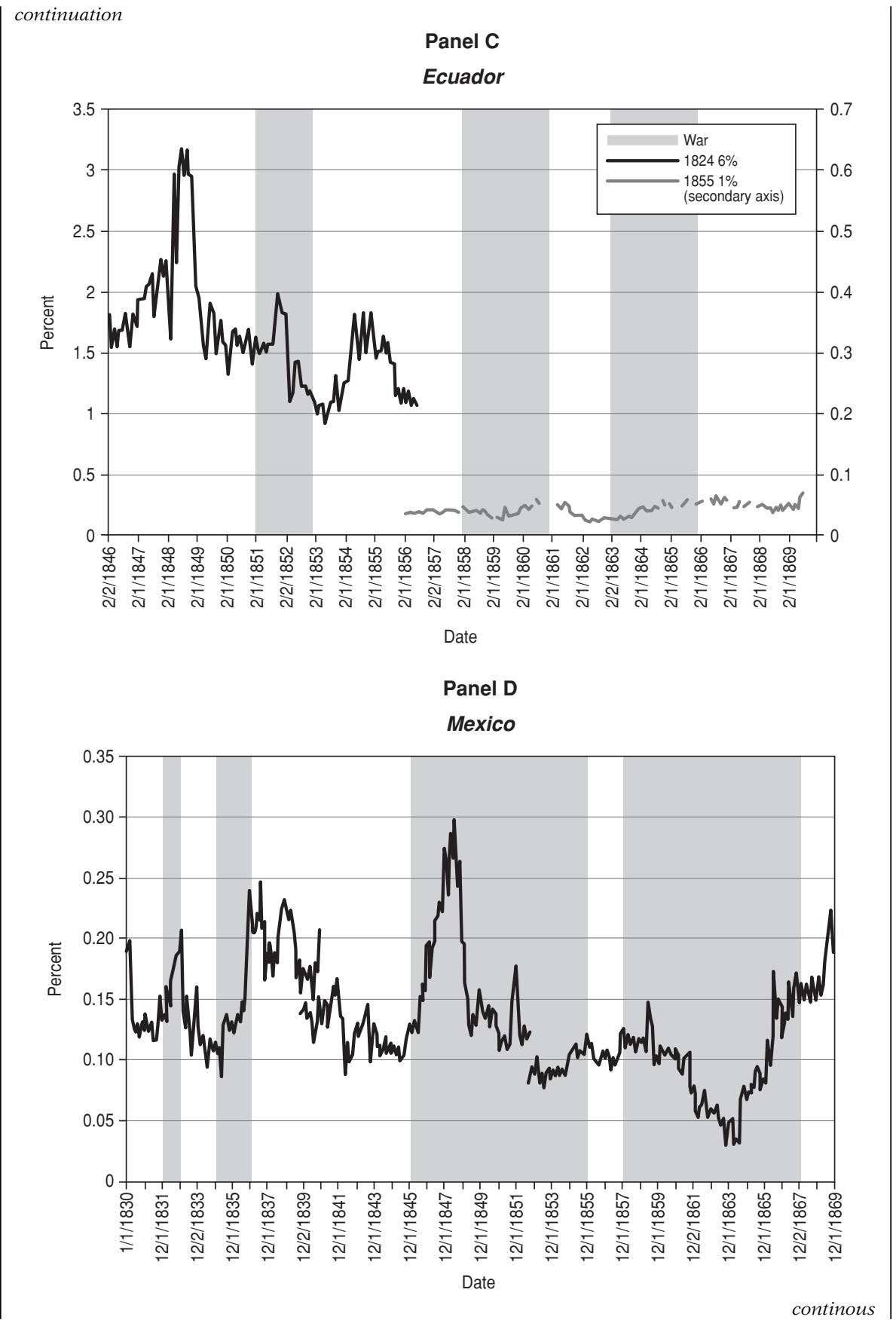




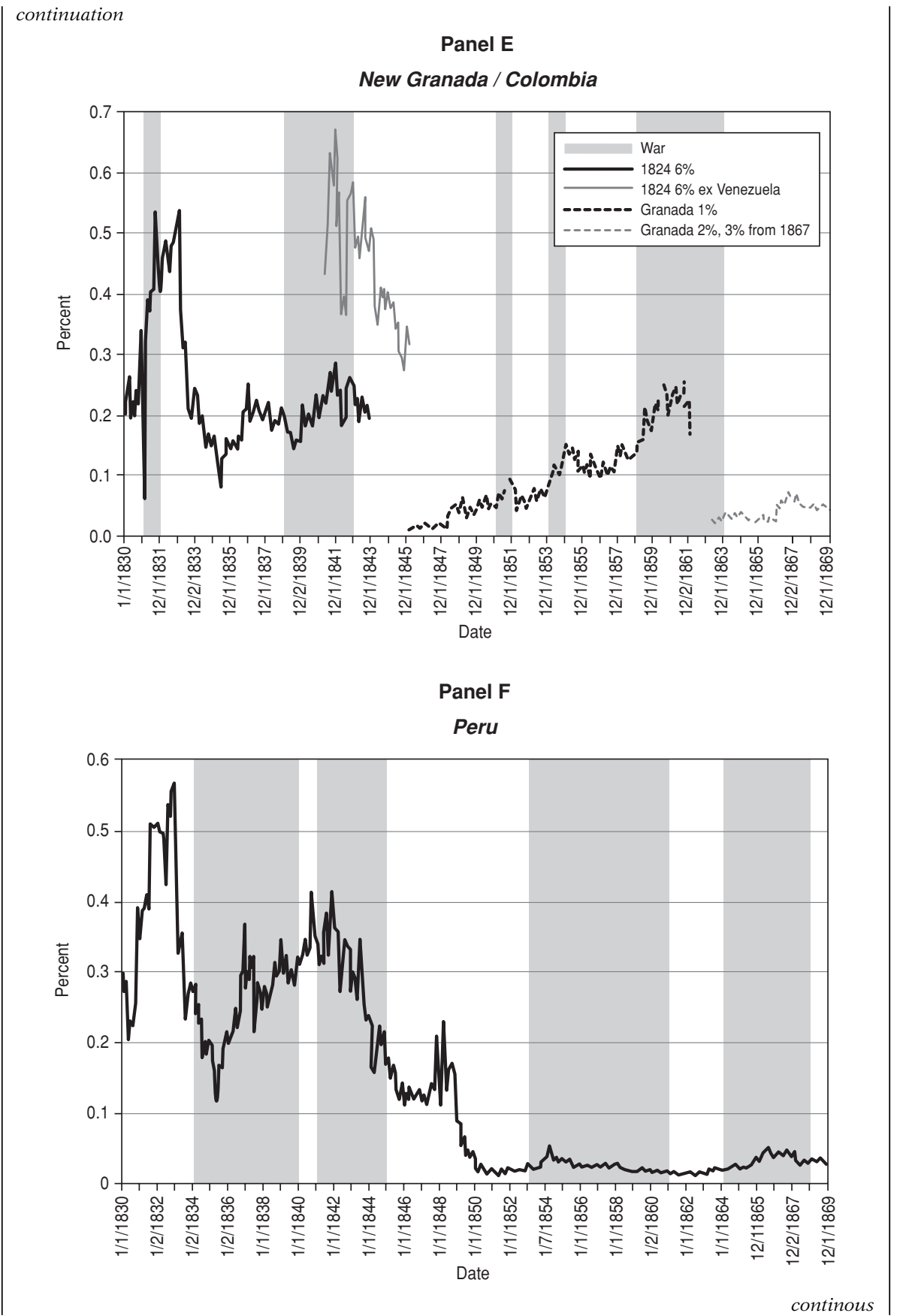




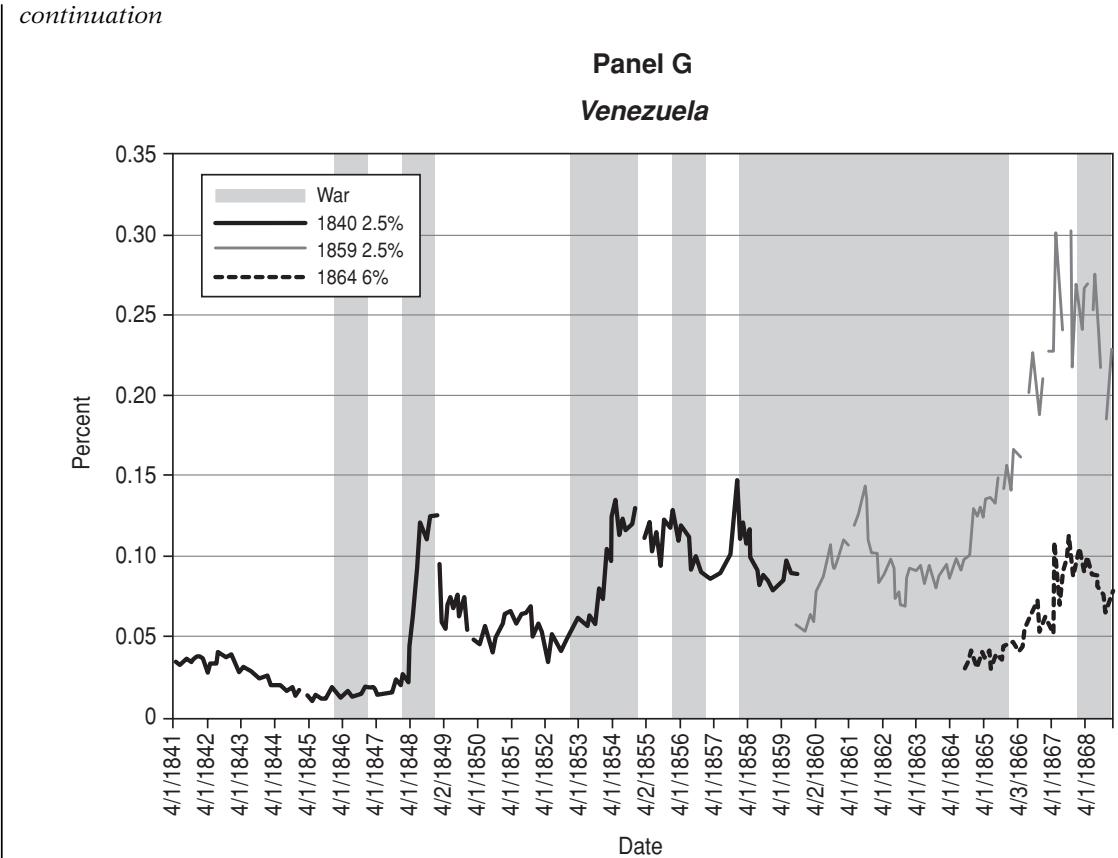

Sources: Course of the Exchange and the Economist.

Note: We used the Gleditsch-Correlates of War criteria for Buenos Aires/Argentina and Mexico, and we used the alternative criteria for the other countries.

settlement of 1855 paid one per cent interest, which resulted in very low prices but also low yield spreads during the 1850s and 1860s. Thus, despite the substantial conflict the country endured and the fact that it was behind on payments, the yield spread on its bonds versus the consol remained below ten percentage points until complete default at the end of our data series.

One can also observe that the countries that carried out successful debt settlements - Argentina, Chile and Peru - maintained relatively small yield spreads, especially in the 1860s during the conflicts for which they negotiated further foreign loans. The wars among the countries that had settled successfully increased the yield spread, but did not appear to shake investors' confidence nearly as much as wars elsewhere. This suggests that the bond market might be more sensitive to military and political conflict in countries that are in default than for countries servicing their debt. This could possibly be due as much to the different types of investors who choose to trade in defaulted debt versus debt that pays regular dividends, as to the economic and/or political fundamentals in those countries. In the case of Peru, Vizcarra (2009) has shown that after settlement, warfare was of secondary 
importance because of the strong credible commitment that guano gave to Peruvian paper.

In order to reach more precise conclusions about the effects of war, we estimate structural breaks in the series of yield spreads using the methodology of Bai and Perron $(1998,2003)$. Their procedure involves the use of a dynamic programming algorithm to identify breakpoints in times series that minimize the sum of squared errors. The procedure estimates both the number of breaks and a constant yield spread between the breaks. The number of breaks is selected using the Bayesian Information Criterion (BIC). The procedure requires the researcher to set a minimum interval of parameter stability. We conducted the estimations using intervals of two and three years ( 24 and 36 monthly observations). We present estimates below using the two-year intervals. The results are robust to estimations using the three-year intervals.

Over a period known for political and economic instability, it is not surprising that there were a number of structural breaks in these time series. The procedure detected a total of fifty-one breaks, thirty-seven of which occurred during or after the end of a war (twenty-eight during war and nine after the end of a war) ${ }^{30}$. These results confirm that foreign investors watched the military and political upheaval that those countries endured during the early republican period closely, and viewed these events as having serious consequences for the likelihood of debt service and default.

In Table 6 we present the two breaks in each series that are associated with the highest percentage change in the yield spread. The table lists the break date and a 95 per cent confidence interval around it. The percentage change in the yield spread refers to the change from the interval prior to the break to that after the break. For example, in the case of Buenos Aires, the largest percentage change in the yield spread was +77.9 per cent (from 16.3 to 29.0 per cent). The procedure estimated a yield spread of 16.3 per cent for a period of 39 months prior to May 1837, and a yield spread of 29.0 per cent for the 44 months after that date. In the interest of space, we present only the data on break dates, confidence intervals and the percentage change in yield spreads.

The breaks that we detect match closely with those visible in the graphs. Many of these breaks coincide with major wars: Buenos Aires in 1847, Chile in 1837, Ecuador in 1861 and 1863, Mexico in 1836 and 1846, New Granada in 1854, and Venezuela in 1848 and 1853. Others coincide with debt settlement, such as Chile in 1841 and Peru in 1849. The percentage change in the estimated yield spreads is extremely high in each case (at least 40 per cent), highlighting both the instability of yields and the dramatic impact of these events. It is also worth noticing that international conflicts stand out as ha-

30 The number of breaks for each country is as follows: Buenos Aires, 10; Chile, 6; Ecuador, 3; Mexico, 11; New Granada, 5; Peru, 6; Venezuela, 10. Full results, covering the 51 breaks for the seven countries, are available upon request. Because of discontinuities in the time series for Ecuador and New Granada, we restricted our estimation in those cases to the longest period of continuous yield spreads (1856-1869 for Ecuador and 1846-1861 for New Granada). 


\section{TABLE 6}

STRUCTURAL BREAKS IN YIELD SPREADS OF SPANISH AMERICAN GOVERNMENT BONDS AGAINST THE BRITISH CONSOL

\begin{tabular}{|c|c|c|c|c|}
\hline Country & Break Date & $\begin{array}{c}95 \% \\
\text { Confidence } \\
\text { Interval }\end{array}$ & $\begin{array}{l}\text { Percentaje } \\
\text { Change in } \\
\text { Yield Spread }\end{array}$ & Event \\
\hline \multirow[t]{2}{*}{ Buenos Aires } & May 1837 & $\begin{array}{l}\text { April 1837- } \\
\text { June } 1837\end{array}$ & +77.9 per cent & $\begin{array}{l}\text { Monetary reform } \\
\text { and large issue of } \\
\text { domestic bonds }\end{array}$ \\
\hline & June 1847 & $\begin{array}{l}\text { Dec. } 1846- \\
\text { July } 1847 \\
\end{array}$ & +68.5 per cent & Blockade \\
\hline \multirow[t]{2}{*}{ Chile } & May 1837 & $\begin{array}{l}\text { April 1837- } \\
\text { June } 1837\end{array}$ & +79.6 per cent & $\begin{array}{l}\text { War with Peru- } \\
\text { Bolivia }\end{array}$ \\
\hline & June 1841 & $\begin{array}{l}\text { May 1841- } \\
\text { Sept. } 1841\end{array}$ & -57.1 per cent & $\begin{array}{l}\text { Anticipation of debt } \\
\text { settlement }\end{array}$ \\
\hline \multirow[t]{2}{*}{ Ecuador } & July 1861 & $\begin{array}{l}\text { June 1861- } \\
\text { Sept. } 1861 \\
\end{array}$ & -41.3 per cent & End of Civil War \\
\hline & Nov. 1863 & $\begin{array}{l}\text { Sept. } 1863- \\
\text { Dec. } 1863\end{array}$ & +88.9 per cent & War with Colombia \\
\hline \multirow[t]{2}{*}{ Mexico } & August 1836 & $\begin{array}{l}\text { July } 1836- \\
\text { Sept. } 1836 \\
\end{array}$ & +68.9 per cent & $\begin{array}{l}\text { Texas obtains } \\
\text { independence }\end{array}$ \\
\hline & Oct. 1846 & $\begin{array}{c}\text { August 1846- } \\
\text { Nov. } 1846 \\
\end{array}$ & +92.5 per cent & $\begin{array}{l}\text { War with United } \\
\text { States }\end{array}$ \\
\hline \multirow[t]{2}{*}{ New Granada } & March 1848 & $\begin{array}{l}\text { Feb. 1848- } \\
\text { April } 1848 \\
\end{array}$ & +188.2 per cent & $\begin{array}{l}\text { Anticipation of } \\
\text { default }\end{array}$ \\
\hline & Feb. 1854 & $\begin{array}{c}\text { Jan. 1854- } \\
\text { March } 1854\end{array}$ & +66.7 per cent & Civil War \\
\hline \multirow[t]{2}{*}{ Peru } & April 1833 & $\begin{array}{l}\text { March 1833- } \\
\text { August } 1833\end{array}$ & -47.3 per cent & $\begin{array}{l}\text { Re-establishment of } \\
\text { diplomatic relations } \\
\text { with Great Britain }\end{array}$ \\
\hline & February 1849 & $\begin{array}{c}\text { Jan. 1849- } \\
\text { March } 1849 \\
\end{array}$ & -81.2 per cent & Debt settlement \\
\hline \multirow[t]{2}{*}{ Venezuela } & March 1848 & $\begin{array}{l}\text { Feb. 1848- } \\
\text { April } 1848 \\
\end{array}$ & +361.1 per cent & Default \& Civil War \\
\hline & December 1853 & $\begin{array}{c}\text { Nov. } 1853- \\
\text { Jan. } 1854 \\
\end{array}$ & +107.1 per cent & Civil War \\
\hline
\end{tabular}

Notes:

* All coefficient estimates are significant at the one per cent level.

** The samples are monthly from Jan. 1830 until Dec. 1869 for Buenos Aires, Chile, Mexico, and Peru. For Ecuador the sample is monthly from Feb. 1856 until Dec. 1869; for New Granada from Feb. 1846 until Dec. 1861; for Venezuela from April 1841 until Jan. 1869.

*** For each, we report the two breaks that resulted in the largest percentage change in the yield spread. See text for explanation of the estimation procedure (Bai and Perron, 1998, 2003). Statistics on the other breaks are available upon request. 
ving the most dramatic effects for most countries. By and large, the evidence from the London capital market shows that military conflicts had a significant effect on investors' perception of sovereign risk.

\section{CONCLUSIONS}

We examined the historical relationship between war and external debt service for seven Spanish American countries before 1870. Data from their Treasury ministries show that, as expected, government revenue often fell, and military spending spiked, during wars. Governments that were in default on foreign debt relied on extensive access to emergency credit that took a striking number of forms, and was often supplied by important domestic players with political and economic clout. Servicing the domestic debt took priority over the external debt as a result.

Taken as a whole, the Treasury data illustrate the intense strains that military conflict placed on these countries, and the calculations that many of the governments made to forgo service on the external debt as a consequence. Yet the countries that had established a record of debt service, and thus were able to borrow abroad, chose to maintain external debt service and often issued new foreign debt during wars. Further, we provide econometric evidence on the yield spreads of sovereign bonds on the London Stock Exchange to show that foreign investors viewed many of the wars in Spanish America as increasing the likelihood of default (or decreasing the likelihood of settlement). Prices fell — and yield spreads rose- during the most serious of these conflicts, often by very large percentages. Indeed, the largest structural breaks we estimate in the series of yield spreads were -in nearly every instance- associated with a war. Our results suggest that not only were wars important, but that they may have been the single most critical factor affecting investors' perceptions of sovereign risk.

Future work might address the observed asymmetry between the «settlement club» of Argentina, Chile and Peru on the one hand, and Ecuador, Mexico, New Granada, and Venezuela, on the other. The fiscal data show that Argentina, Chile and Peru, experienced large increases in government revenues -much larger than in other countries- prior to settlement. Peru experienced a guano boom that was central to its debt settlement and lengthy period of debt service. For Chile and Argentina, a large increase in customs revenues was the key to increase government income. What role did integration with the world economy play? Did all of the default countries have lackluster trade performances? Not only might the failure to settle debt be the result of a slow rate of commercial expansion, but it might also be the case that, as Bergquist (1978) hypothesizes for Colombia, commercial cycles are related to cycles of conflict. Additional research can build upon our results to investigate to what degree trade, war and debt service might be endogenous to one another. 
There is also the vexing question of whether some of these wars had an impact on subsequent political development that in the long run was beneficial for the government's solvency, thereby overriding any shorter run negative ramifications. Indeed, much research in the area will undoubtedly focus on the interaction between changing domestic political institutions fiscal conditions and debt service. The discussion of these critical relationships would help illuminate the complex links between foreign capital, political order and economic growth in the region.

\section{SOURCES}

Committee of Spanish-American Bondholders (1854): Proceedings in relation to the foreign debt of the Republic of Buenos Ayres, London: Richard Clay.

- (1866): Summary Review of Proceedings of the Committee of Spanish American Bondholders from the Commencement, London: Richard Clay.

Economist (1845-1875): London.

Memoria de la Hacienda de Colombia (1826): Colombia.

Memoria de la Hacienda de Nueva Granada (various years): Colombia.

Memoria de la Hacienda de Venezuela (various years): Venezuela.

Resumen de la Hacienda Pública de Chile desde 1833 hasta 1914 (1915): Chile.

Memoria sobre la deuda exterior de Nueva Granada (1860): Colombia.

Times (various years): London.

\section{BIBLIOGRAPHY}

AmARAL, S. (1995): «La deuda pública de Buenos Aires, 1800-1850», in R. LieHR, La deuda pública en América Latina en perspectiva histórica, Frankfurt: Iberoamericana.

BAtes, R.; COATSWORTH, J., and Williamson, J. (2007): «Lost Decades: Lessons from PostIndependence Latin America for Today's Africa». Journal of Economic History, 67 (4), pp. 917-43.

BazANT, J. (1968): Historia de la deuda exterior de México, 1823-1946, México: El Colegio de México.

Berglund, S. (1995): «The Public Debt of Venezuela: Causes and Effects, 1830-1870», in R. LIEHR, La deuda pública en America Latina en perspectiva histórica, Frankfurt: Iberoamericana.

Bergouist, C. (1978): Coffee and Conflict in Colombia, 1886-1910, Durham, NC: Duke University Press.

Bethell, L. (ed.) (1987): Spanish America after Independence, 1820-1870, Cambridge: Cambridge University Press.

BorCHARD, E. (1951): State Insolvency and Foreign Bondholders. General Principles, vol. 1, New Haven: Yale University.

Bulow, J., and Rogoff, K. (1989): «Sovereign Debt: Is to Forgive to Forget?». American Economic Review, 79 (1), pp. 43-50.

Burgin, M. (1946): The Economic Aspects of Argentine Federalism, 1820-1852, Cambridge: Harvard University Press.

Carmagnani, M. (1983): «Finanzas y Estado en México, 1820-1880». Ibero-amerikanisches Archiv, 9, pp. 279-314. 
Centeno, M. A. (2002): Blood and Debt: War and the Nation-State in Latin America, University Park, PA: Pennsylvania State University Press.

COATSWORTH, J. (2008): "Inequality, Institutions and Economic Growth in Latin America». Journal of Latin American Studies, 40, pp. 545-569.

- (1866): Summary Review of the Proceedings of the Committee of Spanish American Bondholders from the Commencement, London: Richard Clay.

Cortés-Conde, R. (1989): Dinero, Deuda y Crisis: Evolución Fiscal y Monetaria en la Argentina, 1862-1890, Buenos Aires: Editorial Sudamericana.

Costeloe, M. (2003): Bonds and Bondholders: British Investors and Mexico's Foreign Debt, 1824-1888, Westport, CT: Praeger.

Dawson, F. (1990): The First Latin American Debt Crisis, New Haven: Yale University Press.

Deas, M. (1982): «The Fiscal Problems of Nineteenth-Century Colombia». Journal of Latin American Studies, 14, pp. 287-328.

Eaton, J., and Gersovitz, M. (1996): «Debt with Potential Repudiation: Theoretical and Empirical Analysis». Review of Economic Studies 48, pp. 239-309.

EAstwick, E. (1868): Venezuela: Sketches of Life in a South American Republic; with the History of the Loan of 1864, London: Chapman and Hall.

FEnN, C.: Compendium of the English and Foreign Funds, London: Effingham Wilson, various issues.

Flandreau, M., and Flores, J. (2007): «Bonds and Brands: Lessons from the 1820s». Unpublished manuscript.

Flandreau, M., and Zumer, F. (2004): The Making of Global Finance, 1880-1913, Paris: OECD.

Fowler, W. (2000): "Civil Conflict in Independent Mexico, 1821-1857: An Overview», in R. EARLE (ed.), Rumours of Wars: Civil Conflicts in Nineteenth-Century Latin America, London: University of London.

GLEDITSCH, K. (2004): «A Revised List of Wars Between and Within Independent States, 1816-2002». International Interactions, 30, pp. 231-262.

Gootenberg, P. (1996): "Paying for Caudillos: The Politics of Emergency Finance in Peru, 1820-1845», in V. Peloso and B. Tenenbaum (eds.), Liberals, Politics and Power, Athens, GA: University of Georgia Press.

GREAT BRITAIN (1847): Correspondence between Great Britain and Foreign Powers and Communications from the British Government to Claimants relating to Loans Made by British Subjects, 1823-1847, Sessional Papers, London.

HalPerin D. T. (1982): Guerra y finanzas en los orígenes del Estado argentino, Buenos Aires: Editorial de Belgrano.

Irigoin, M. A. (2000): Finance, Politics and Economics in Buenos Aires, 1820s to 1860s, $\mathrm{Ph}$. D. thesis, University of London.

Jaramillo, J.; Maisel, A., and Urrutia, M. (2001): "Continuities and Discontinuities in the Fiscal and Monetary Institutions of New Granada, 1783-1850», in M. BoRDo and R. CORTÉs-CONDE (eds.), Transferring Wealth and Power from the Old to the New World, Cambridge: Cambridge University Press.

LieHR, R. (1989): "La deuda exterior de la Gran Colombia frente a Gran Bretaña, 18201860», in R. Liehr (ed.), América Latina en la época de Simón Bolívar, Berlin: Colloquium Verlag.

MamalaKis, M. (1978): Historical Statistics of Chile, Westport, CT: Greenwood Press.

Marichal, C. (1989): A Century of Debt Crises in Latin America, Princeton: Princeton University Press.

Marichal, C., and Carmagnani, M. (2001): «Mexico: From Colonial Fiscal Regime to Liberal Financial Order», in M. BORDo and R. CORTÉs-CONDE (eds.), Transferring 
Wealth and Power from the Old to the New World, Cambridge: Cambridge University Press.

Mitchener K., and Weidenmier, M. (2005): «Supersanctions and Sovereign Debt Repayment». NBER Working Paper 11472.

Neal, L. (1998): "The Financial Crisis of 1825 and the Restructuring of the British Financial System», St. Louis: Federal Reserve Bank of St. Louis Review.

North, D., and Weingast, B. (1989): «Constitutions and Commitment». Journal of Economic History, 49, pp. 803-832.

North, D.; Summerhill, W., and Weingast, B. (2000): «Order, Disorder and Economic Change: Latin America versus North America», in B. B. DE MesouitA and H. Root (eds.), Governing for Prosperity, New Haven: Yale University Press.

PlatT, D. C. M. (1968): Finance, Trade and Politics in British Foreign Policy, 1815-1914, Oxford: Clarendon Press.

- (1983): «Foreign Finance in Argentina for the First Half-Century of Independence». Journal of Latin American Studies, 15, pp. 23-47.

Quiroz, A. (1995): «Public Debt and the Domestic Financial Structure in Peru, 1850-

1914», in R. LIEHR (ed.), La deuda pública en América Latina en perspectiva histórica, Frankfurt: Iberoamericana.

- (1987): La deuda defraudada. Consolidación de 1850 y dominio económico en el Perú, Lima: Instituto Nacional de Cultura.

RipPy, J. F. (1959): British Investments in Latin America, 1822-1949, Minneapolis: University of Minnesota Press.

Rodríguez, L. (1985): The Search for Public Policy: Regional Politics and Government Finances in Ecuador, 1830-1940, Berkeley: University of California Press.

SAFFORD, F. (1992): «The Problem of Political Order in Early Republican Spanish America». Journal of Latin American Studies, 24, pp. 83-97.

- (2000): «Reflections on the Internal Wars in Nineteenth-Century Latin America», in R. EARLE (ed.), Rumours of Wars: Civil Conflicts in Nineteenth-Century Latin America, London: University of London.

Scheina, R. (2003): Latin America's Wars: The Age of the Caudillo, 1791-1899, Dulles, VA: Brassey's.

Singer, J. D., and Small, M. (1995): Correlates of War Project: International and Civil War Data, 1816-1992, Ann Arbor: ICPSR.

Stevens, D. (1991): Origins of Instability in Early Republican Mexico, Durham: Duke University Press.

Summerhill, W. (2008): «Sovereign Borrowing in Imperial Brazil». Unpublished Manuscript.

Tantalean Arbulu, J. (1983): Política económico-financiera y la formación del Estado, Lima: CEDEP.

Tenenbaum, B. (1995): «Mexico's Money Market and the Internal Debt, 1821-1855», in R. LieHr (ed.), La deuda pública en América Latina en perspectiva histórica, Frankfurt: Iberoamericana.

- (1986): The Politics of Penury: Debts and Taxes in Mexico, 1821-1856, Alburquerque: University of New Mexico Press.

TERAN, E. (1896): Informe al Jefe Supremo General Eloy Alfaro sobre la deuda anglo-ecuatoriana, Quito: Imprenta Nacional.

Tomz, M. (2007): Reputation and International Cooperation. Sovereign Debt across Three Centuries, Princeton: Princeton University Press.

VizCARra, C. (2009): «Guano, Credible Commitments, and Sovereign Debt Repayment in Nineteenth-Century Peru», The Journal of Economic History, 69 (2), pp. 358-387. 


\section{APPENDIX}

TABLE A

WARS IN SPANISH AMERICA, 1825-1870

\begin{tabular}{|c|c|c|}
\hline Country & Years of Conflict & Opponent(s) \\
\hline Buenos Aires & $\begin{array}{l}1825-1828 \\
1828-1831 \\
1833-1835 \\
1837-1838 \\
1838-1852 \\
\mathbf{1 8 3 8 - 1 8 3 9 ;} \mathbf{1 8 4 5 - 1 8 4 7} \\
1859 \\
1861 \\
1863 \\
1865-1870 \\
1870-1871\end{array}$ & $\begin{array}{l}\text { Brazil } \\
\text { Civil } \\
\text { Civil } \\
\text { Bolivia-Peru } \\
\text { Uruguay-European Allies- } \\
\text { Civil } \\
\text { France-United Kingdom } \\
\text { Civil } \\
\text { Civil } \\
\text { Civil } \\
\text { Paraguay } \\
\text { Civil }\end{array}$ \\
\hline Chile & $\begin{array}{l}1825-1826 \\
1829-1830 \\
1836-1839 \\
1851 \\
1859 \\
\mathbf{1 8 6 5 - 1 8 6 6}\end{array}$ & $\begin{array}{l}\text { Spain (Independence) } \\
\text { Civil } \\
\text { Peru-Bolivia } \\
\text { Civil } \\
\text { Civil } \\
\text { Spain }\end{array}$ \\
\hline Ecuador & $\begin{array}{l}1825-1826 \\
1828-1829 \\
1830-1832 \\
1833-1834 \\
1840-1841 \\
1845 \\
1851-1852 \\
1858-1860 \\
1860 \\
1863 \\
1864-1865\end{array}$ & $\begin{array}{l}\text { Spain in Peru } \\
\text { Peru } \\
\text { Gran Colombia } \\
\text { Civil (Chihuahuas) } \\
\text { Border Conflict } \\
\text { Civil } \\
\text { Civil } \\
\text { Peru-Civil } \\
\text { Granadine Confederation } \\
\text { United States of Colombia } \\
\text { Civil }\end{array}$ \\
\hline Mexico & $\begin{array}{l}1827 \\
1829 \\
1832 \\
1835-1836 \\
1836-1843 \\
\mathbf{1 8 3 8} \\
1844-1845 \\
\mathbf{1 8 4 6 - 1 8 4 8} \\
1847-1855\end{array}$ & $\begin{array}{l}\text { Civil } \\
\text { Spain } \\
\text { Civil } \\
\text { Civil (Texas) } \\
\text { Civil and Texas } \\
\text { France } \\
\text { Civil (Paredes-Santa Anna) } \\
\text { United States } \\
\text { Civil (Caste) }\end{array}$ \\
\hline
\end{tabular}


continuation

\begin{tabular}{|c|c|c|}
\hline Country & Years of Conflict & Opponent(s) \\
\hline & $\begin{array}{l}1854-1856 \\
1857-1860 \\
\mathbf{1 8 6 2 - 1 8 6 7}\end{array}$ & $\begin{array}{l}\text { Civil (Ayutla Revolt and } \\
\text { Prelude to Reforma) } \\
\text { Civil (Reforma) } \\
\text { France }\end{array}$ \\
\hline $\begin{array}{l}\text { New Granada/Granadine } \\
\text { Confederation/United } \\
\text { States of Colombia }\end{array}$ & $\begin{array}{l}1825-1826 \\
1828-1829 \\
1830-1832 \\
1839-1842 \\
1851 \\
1854 \\
1860-1862 \\
1863\end{array}$ & $\begin{array}{l}\text { Spain in Peru } \\
\text { Peru } \\
\text { Gran Colombia } \\
\text { Civil } \\
\text { Civil } \\
\text { Civil } \\
\text { Civil } \\
\text { Ecuador }\end{array}$ \\
\hline Peru & $\begin{array}{l}1825-1826 \\
1828-1829 \\
1834-1835 \\
1836-1839 \\
1841-1842 \\
1842-1844 \\
1853-1855 \\
1856-1858 \\
1858-1860 \\
\mathbf{1 8 6 4 - 1 8 6 6} \\
1867-1868\end{array}$ & $\begin{array}{l}\text { Spain (Independence) } \\
\text { Gran Colombia } \\
\text { Civil } \\
\text { Chile } \\
\text { Bolivia } \\
\text { Civil } \\
\text { Civil } \\
\text { Civil } \\
\text { Ecuador } \\
\text { Spain } \\
\text { Civil }\end{array}$ \\
\hline Venezuela & $\begin{array}{l}1825-1826 \\
1828-1829 \\
1831 \\
1835-1837 \\
1846 \\
1848-1849 \\
1859-1863 \\
1868-1871\end{array}$ & $\begin{array}{l}\text { Spain in Peru } \\
\text { Peru } \\
\text { Civil } \\
\text { Civil } \\
\text { Civil } \\
\text { Civil } \\
\text { Civil (Federal) } \\
\text { Civil }\end{array}$ \\
\hline
\end{tabular}

Sources: Gleditsch (2004), Scheina (2003), Bethell (1987).

Note: Italicized years and wars refer to differences between the two definitions of wars described in the text. Years in bold are an incomplete list of blockade years. 